\title{
Morphological and histological characters of penile organization in eleven species of molossid bats
}

\author{
Manuela T. Comelis $^{\mathrm{a}}$, Larissa M. Bueno ${ }^{\mathrm{a}}$, Rejane M. Góes ${ }^{\mathrm{b}}$, S.R. Taboga ${ }^{\mathrm{b}}$, \\ Eliana Morielle-Versute ${ }^{\text {a,* }}$ \\ ${ }^{a}$ Department of Zoology and Botany, São Paulo State University (UNESP), Institute of Biosciences, Humanities and Exact Sciences (Ibilce), Campus São José do Rio Preto, \\ São Paulo 15054-000, Brazil \\ ${ }^{\mathbf{b}}$ Department of Biology, São Paulo State University (UNESP), Institute of Biosciences, Humanities and Exact Sciences (Ibilce), Campus São José do Rio Preto, São Paulo \\ 15054-000, Brazil
}

\section{A R T I C L E I N F O}

\section{Keywords:}

Glans penis

Baculum

Accessory cavernous tissue

Molossidae

\begin{abstract}
A B S T R A C T
The penis is the reproductive organ that ensures efficient copulation and success of internal fertilization in all species of mammals, with special challenges for bats, where copulation can occur during flight. Comparative anatomical analyses of different species of bats can contribute to a better understanding of morphological diversity of this organ, concerning organization and function. In this study, we describe the external morphology and histomorphology of the penis and baculum in eleven species of molossid bats. The present study showed that penile organization in these species displayed the basic vascular mammalian pattern and had a similar pattern concerning the presence of the tissues constituting the penis, exhibiting three types of erectile tissue (the corpus cavernosum, accessory cavernous tissue, and corpus spongiosum) around the urethra. However, certain features varied among the species, demonstrating that most species are distinguishable by glans and baculum morphology and glans histological organization. Major variations in glans morphology were genus-specific, and the greatest similarities were shared by Eumops species and $N$. laticaudatus. The greatest interspecific similarities occurred between M. molossus and M. rufus and between Eumops species. Save for M. molossus and M. rufus, morphology of the baculum was species-specific; and in E. perotis, it did not occur in all specimens, indicating that it is probably under selection. In the histological organization, the most evident differences were number of septa and localization of the corpora cavernosa. In species with a baculum (Molossus, Eumops and Nyctinomops species), the corpora cavernosa predominantly occupied the dorsal region of the penile glans and is associated with the proximal (basal) portion of the baculum. In species that do not have a baculum (Cynomops, Molossops and Neoplatymops species), the corpora cavernosa predominantly occupied the ventro-lateral region of the glans.
\end{abstract}

\section{Introduction}

The mammalian penis is a complex structure, and it evolved more divergently than those related to non-intruding organs (Arnqvist, 1997; Ramm, 2007; Klaczko et al., 2015; Jones et al., 2016; Schultz et al., 2016a,b; Orr and Brennan, 2016). The primary sources of this external morphological diversity are attributed to post-copulatory sexual selection mechanisms, in which sperm competition appears to be a crucial force in the evolutionary origin of the penis (Arnqvist, 1998; Eberhard, 2001; Hosken and Stockley, 2004; Ramm, 2007; Simmons et al., 2009; Cayetano et al., 2011; Simmons and Garcia-Gonzalez, 2011; Hotzy et al., 2012; Stockley et al., 2013; Simmons and Firman, 2014).

The high degree of interspecific variation in penile (glans penis) morphology and in os penis or baculum, present inside glans of species of
Afrosoricida, Carnivora, Chiroptera, Erinaceomorpha, Primates, Soricomorpha, Lagomorpha, and Rodentia (Patterson and Thaeler, 1982; Ryan, 1991a, 1991b; Ramm, 2007; Dixson, 2012; Herdina et al., 2010, 2014, 2016; Rodriguez et al., 2011; Weimann et al., 2014; Comelis et al., 2015), makes them a useful character in examining relationships among taxa in which convergence of characters is a common event (Patterson and Thaeler, 1982; Hill and Harrison, 1987; Thomas et al., 1994; Benda et al., 2004; Benda and Reiter, 2006; Jacobs et al., 2013; Woolley et al., 2015).

Penile characteristics have proved to be useful in distinguishing different taxa of Mammalia, highlighting some rodent genera (Lessa and Cook, 1989; Williams et al., 1980), species of carnivores from Mustelidae family (Burt, 1960; Long and Frank, 1968; Long, 1969; Baryshnikov et al., 2003), some primate genera (Perkin, 2007; Fooden,

\footnotetext{
* Corresponding author.

E-mail address: morielle@ibilce.unesp.br (E. Morielle-Versute).
} 
2006), and species of bats, in which the analysis of penile characters assumed a significant role in taxonomic considerations (Benda and Tsytsulina, 2000; Cotterill 2002; Herdina et al., 2014; Reardon et al., 2014; Gregorin and Cirranello, 2016). However, information about the intra- and interspecific variations of penile morphology, and presence or absence of a baculum (penile bone) between closely related species are still restricted to a few species. This fact hinders any attempt to interpret this character in phylogenetic analyzes.

Molossidae is the 4th largest family of the Chiroptera, and most of the 100 species that constitute it (Simmons, 2005) are similar in appearance and can only be externally distinguished by subtle anatomical features, such as the extent of ear joining, shape of the antitragus, wrinkles on the lips, and the presence of rump bristles (Freeman 1981; Gregorin and Cirranello, 2016). The recognition of species, as well as the validity of some genera and the relationships above the specieslevel remain unclear (Ammerman et al., 2012; Gregorin and Cirranello, 2016). The incongruent results of several studies addressing different sets of morphological and/or molecular characters have been attributed to the need to include additional taxa and data in such studies.

Cynomops, Eumops, Molossops, Molossus, Neoplatymops and Nyctinomops represent six of the 16 genera of Molossidae recognized, and Eumops is the most diverse genus in the Neotropics (Medina et al., 2014). The complexity is even greater within the genus, since subspecies are recognized for many of its species (Eger, 1977; Timm and Genoways 2004; Simmons, 2005; Gregorin, 2009; Bartlett et al., 2013; Moras et al., 2016).

Ryan (1991a, 1991b) was one of the first to study the external morphology of the glans in Molossidae species. In the two publications, he presented information on penile morphology in scanning electron microscopy of ten species of Molossidae, providing useful information for the recognition of several characteristics within the group.

Add to this the important taxonomic traits of the penis, with its crucial role in reproductive success of different species of mammals, especially bats where copula is reported to occur even during flight in some species (aerial mating) (Cryan, 2008; Cryan et al., 2012); or for example, in copulations where the male has to remove the copulatory plugs in females that mate with multiple partners (Keeley and Keeley, 2004). In this context, an aspect that has not yet been explored is the composition and microanatomy of internal penile tissues. Tissues constituting the penis are responsible for success in intromission and ejaculation, where erectile tissues, i.e., the corpus spongiosum and corpus cavernosum, together with the urethra, epithelial specializations of the glans, and the baculum, participate directly (Hull and Dominguez, 2007; Hull and Rodríguez-Manzo, 2009; Herdina et al., 2015a,b).

The aim of the present study was to characterize histomorphologically the penis and the baculum of eleven species of bats belonging to the Molossidae family.

\section{Materials and methods}

\subsection{Specimens}

Studies were performed in sixty-seven adults and one juvenile male specimen representing eleven species of six molossid genera. Bats were aged as adults based on body weight, complete ossification of the metacarpal-phalangeal epiphyses, and degree of tooth wear (De Knegt et al., 2005).

Penises of nineteen fresh C. planirostris (2), E. bonariensis (2), E. glaucinus (2), E. perotis ( $2+1$ juvenile), M. temminckii (3), M. molossus (3), M. rufus (3) and N. laticaudatus (1) specimens were used for histological analyses. Specimens were collected in northwest São Paulo state, Brazil (São José do Rio Preto: 49W $220450020 S 490$ 1100) with authorization from the Brazilian institution responsible for wild animal care (Instituto Brasileiro do Meio Ambiente, IBAMA, License Number: 21707-1; Sisbio: 59765825-13/04/2010).

Glans and bacular morphology were analyzed in forty-nine ethanol preserved adult males of Cynomops abrasus (3), Cynomops planirostris (4), Eumops auripendulus (5), Eumops bonariensis (2), Eumops glaucinus (5), Eumops perotis (5), Molossops temminckii (5), Molossus molossus (5), Molossus rufus (5), Neoplatymops matogrossensis (5) and Nyctinomops laticaudatus (5). All were preserved in the Chiroptera Collection of São Paulo State University (DZSJRP).

The study proposal was approved by the Institutional Ethics Committee for Animal Experimentation (Document: Protocol. 013/ 2009 CEEA/IBILCE-UNESP). Vouchers are deposited in the Chiroptera collection (DZSJRP-UNESP).

\subsection{Animal processing for baculum visualization and histological analysis}

Fresh animals were killed by cervical dislocation, and penises were removed by dissecting proximally to the ischial attachment of the penis separating the penile crurae from the bone. Next, specimens were fixed in buffered paraformaldehyde fixative solution at room temperature for 48 hours, dehydrated in a series of ethanol (50 to 100\%), clarified in xylene, embedded in paraffin and sectioned $(5 \mu \mathrm{m})$ in a Leica RM 2155 microtome. Hematoxylin-eosin staining was used for general characterization of the penises and to distinguish cell types. Masson Tushmann's blue was used to highlight collagen (blue) and smooth muscle (orange). Microscopic analyses were performed using a light microscope (Zeiss Axio Imager-A2) and image scanner (Olympus BXVCB) coupled with a capture and image analysis software (Axiovision Rel 4.8 and VS-ASW software, respectively).

Penises of preserved specimens were diaphonized. After removal by incision proximally to the ischial attachment of the penis, they were placed in a neutralized solution of saturate sodium borate and cleared and softened in an alkaline solution of 5\% trypsin in $1 \% \mathrm{KOH}$ for at least two hours. The prepuce was then removed to expose the glans, and penises were transferred to a staining solution of 5\% Alizarin Red (Taylor, 1967) for 2 hours to identify bone structure (baculum). Diaphonized penises were analyzed under a Leica MZ 16 stereomicroscope coupled with a Leica DFC 295 digital camera and capture and image analysis software (Leica Application Suite-LAS, Version 3.8). After documentation, the length of the glans penises was measured and then dissected to isolate the baculum. The baculum was then photographed, and length (from base to apex) and width (from the more basal region) measurements were recorded.

Descriptions and orientation of the baculum in the glans refer to a flaccid and cranially directed organ from a ventral urethral perspective. To compare results with published data for other bat species, we adopted the terminology suggested by Ryan (1991a, 1991b) to identify the glans, which state that the glans in Chiroptera is that part of the penis distal to the glans-prepuce junction.

\section{Results}

\subsection{General penile morphology}

In the eleven species analyzed, the penis consisted of two parts: the body and the glans. The body encompasses most of the pendulous portion of the penis, and the glans, in turn, is the distal portion following the glans-prepuce junction (Fig. 1). The prepuce is the sheath of hair-covered tissue that covers the entire outer surface of the penis, including the glans, when the penis is flaccid. Morphology and size of the glans were widely variable among species.

\subsection{External glans morphology}

\subsubsection{Genus Cynomops (Thomas, 1920)}

The length of the glans varied intra- and interspecifically. In $C$. abrasus, it reached approximately $4.0 \mathrm{~mm}$ and $1.74 \mathrm{~mm}$ in C. planirostris. In both species the glans presented ellipsoidal morphology, with a rounded apex (Fig. 2A-F). The ventral surface of the glans, in both 
A

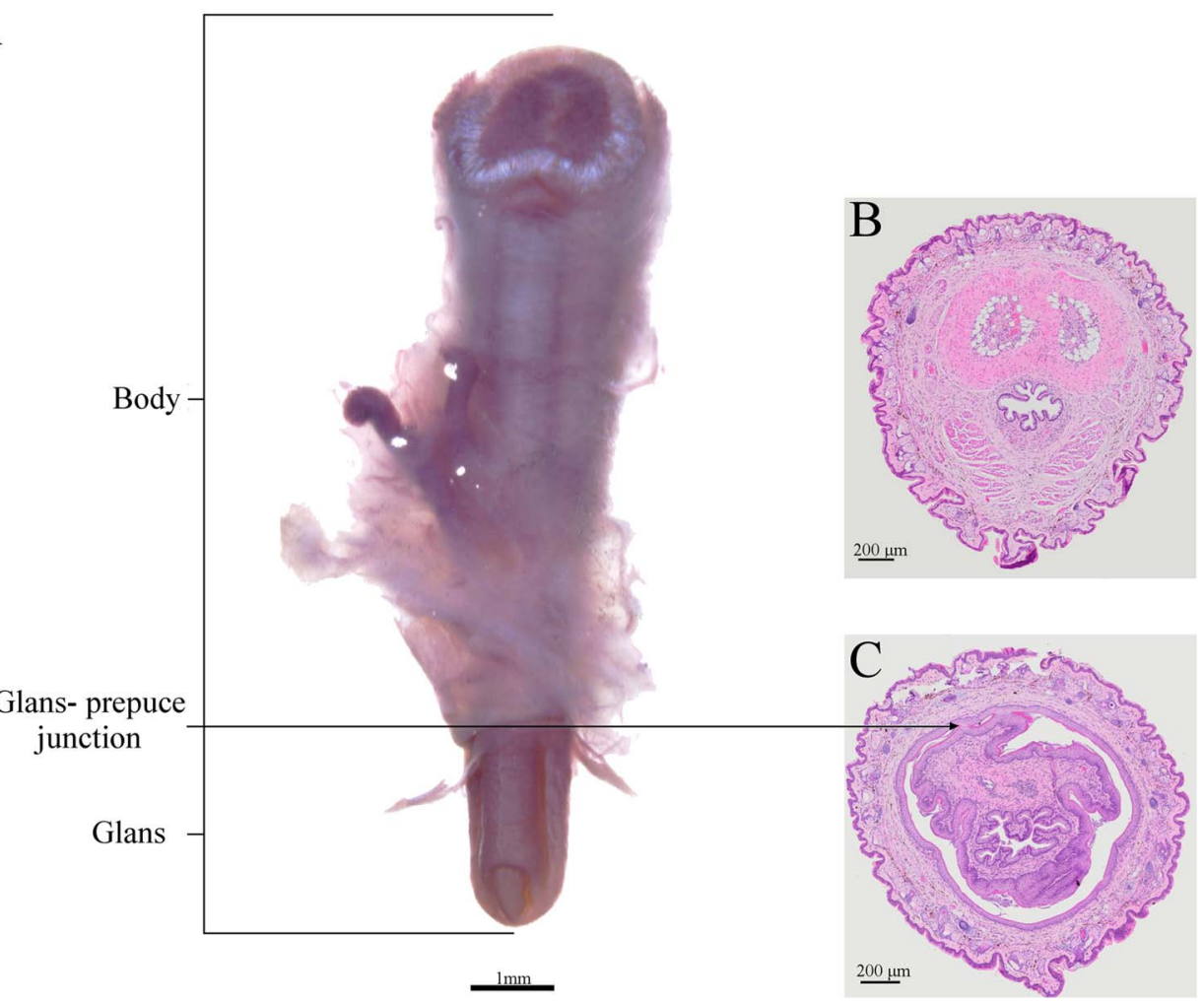

Fig. 1. Illustration of the parts that make up penile glans in molossid bats. (A) Ventral view of Eumops perotis glans penis after diaphonization. (B) Section of the body. (C) Cut at the beginning of the glans. The arrow points to the end of the glans-prepuce junction.

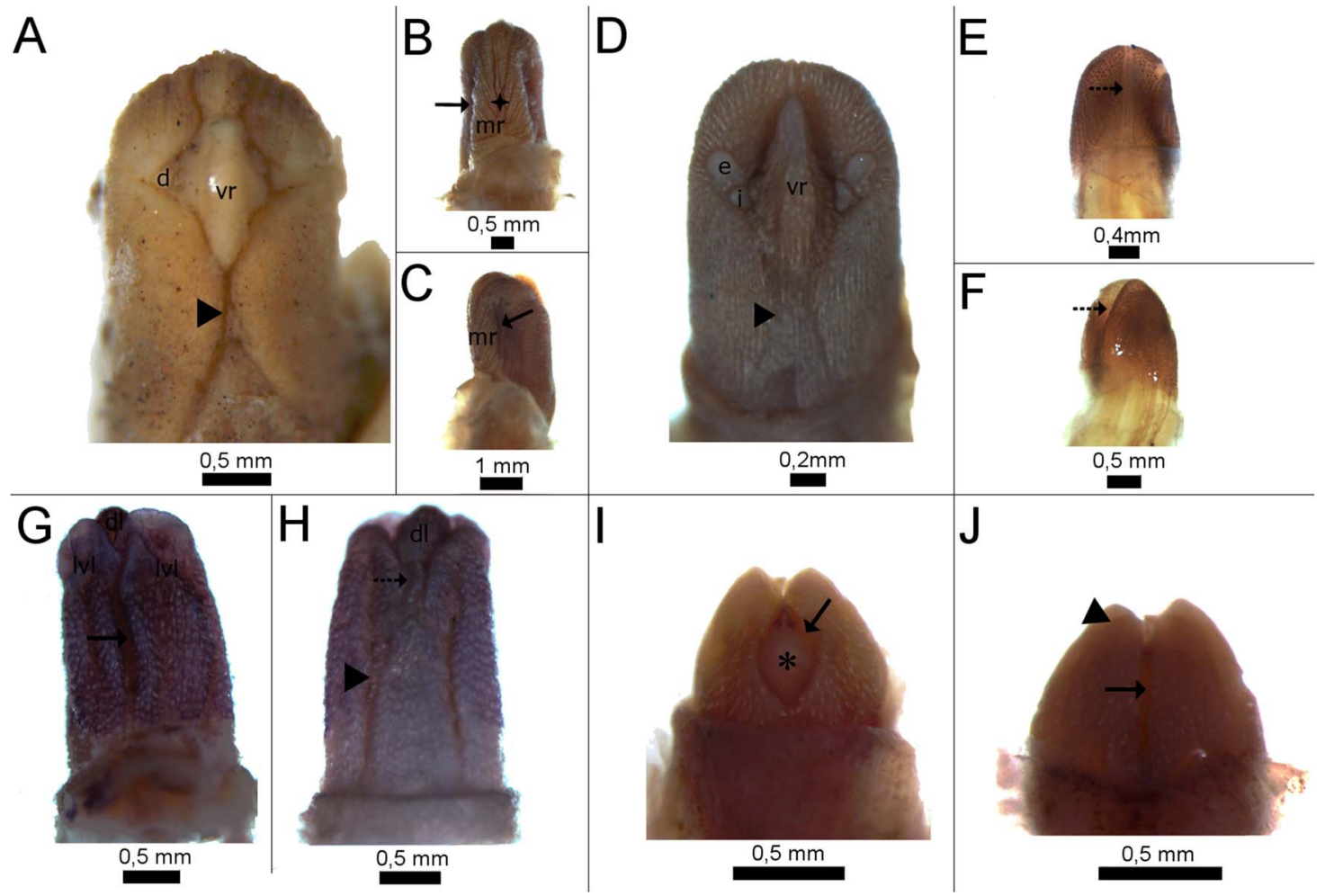

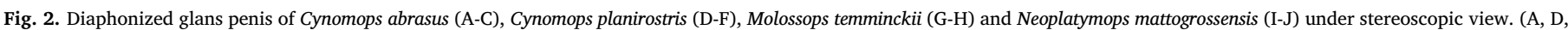

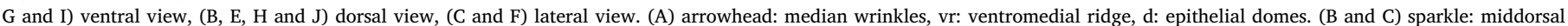

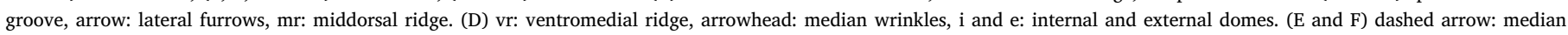

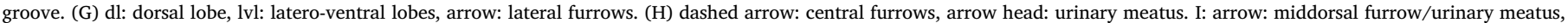
asterisk: midventral projection. (J) arrowhead: dorso-lateral folds. 
species (Fig. 2A and D), presented two median wrinkles with an hourglass-like morphology (wider in the proximal portion, narrow in the middle, widening again towards the apex). Above these wrinkles there was a ventromedial ridge with lanceolate shape, which did not extend to the apex. Behind this ridge was the urinary meatus. Midventral wrinkles were deeper in C. abrasus (Fig. 2A) than in C. planirostris (Fig. 2D). The ventral lanceolate ridge was long and narrow in $C$. planirostris, presenting laterally with two pairs of epithelium domes: a smaller internal and a larger external dome (Fig. 2D); whereas, in $C$. abrasus, the ventral lanceolate ridge was shorter and wider and had only one small pair of epithelial domes (Fig. 2A).

The dorsal surface of $C$. abrasus' glans was marked by two lateral furrows, which formed a cylindrical middorsal ridge that extended the entire length of the glans (Fig. 2B and C). In the middle of this ridge there was a middorsal groove (Fig. 2B). In C. planirostris' dorsal surface there was a deep median groove, which extended its entire length separating it into two equivalent regions. Although the groove reached the distal apical rounded portion, it did not extend toward the ventral surface (Fig. 2E and F).

In both species the outer surface of the glans was covered by small proximal-directed spiniform epidermal projections, with bases larger than apices. These projections did not occur in the central lanceolate projection nor on the surface of the ventral domes (Fig. 2). No os penis was observed inside the glans of the species.

\subsubsection{Genus Eumops (Miller, 1906)}

General morphology of the glans was similar in the four species of Eumops analyzed. They had an arrow shape, narrower at the base and wider at the apex, and they were dorso-ventrally compressed. The outer surface of the glans penis lacked epithelial spines (Fig. 3A-B, D-E, G-H and $\mathrm{J}-\mathrm{K}$ ). Despite these general similarities there were some important species-specific features in their morphology and size that must be considered.

Glans lengths varied from $1.2 \mathrm{~mm}$ to $2.42 \mathrm{~mm}$. Mean values observed for the species were $1.73 \mathrm{~mm}$ for $E$. auripendulus, $1.2 \mathrm{~mm}$ for $E$. bonariensis, $1.61 \mathrm{~mm}$ for E. glaucinus and $2.42 \mathrm{~mm}$ for $E$. perotis. The glans of E. auripendulus and E. glaucinus presented greater morphological similarity (Fig. 3A-B and G-H), which decreased progressively for E. bonariensis and E. perotis (Fig. 3D-E and J-K).

In E. glaucinus and E. auripendulus, the glans was narrower and oval at the base and widens at approximately $1 / 4$ of the prepuce-glans distance. Its widest point was approximately $3 / 4$ of the base. From this point, the glans narrowed abruptly towards the apex, where it ended at a sharp point (Fig. 3A-B and G-H). Constituting the largest portion of the glans, there were two lateral lobes, which could be seen on both surfaces of the glans. Dorsally, the glans of the two species was marked by the presence of a pair of central grooves, which marked the lateral lobes on this surface (Fig. 3B and H).

Ventrally, there were two lateral furrows that formed a cylindrical ventromedial ridge that covered $3 / 4$ of the glans. In the apical portion of the ventral surface, there was a circular slit, the urinary meatus, which began in the subapical portion and extended to the apex. Just above the urinary meatus there was a ridge with a drop shape, a broad rounded base and pointed apex. This drop-shaped ridge is called the bacular mound (Fig. 3A and G). The urinary meatus was limited superiorly by the inferior border of the bacular mound and inferiorly by the upper border of the ventromedial ridge. In both species, only the tip of the baculum reached the bacular mound. In E. auripendulus, the bacular mound was the tip of the glans; whereas, in E. glaucinus, the bacular mound did not extend into the apex (Fig. 3A and G).

$E$. bonariensis' and E. perotis' glans had a cylindrical morphology. In E. bonariensis, lateral lobes were absent and the bacular mound was more oval and extended into the apex. The urinary meatus had a subapical opening. Only the tip of the baculum was in the bacular mound (Fig. 3D and E).

On the ventral surface of E. perotis' glans, a furrow surrounded the entire border of the glans. In the middle of the glans there was a prominent ridge that enclosed the urethra and ended distally on the urinary meatus. The bacular mound was located above the urinary meatus, and similar to other species, it had a broad rounded base and a sharp apex (Fig. 3J). In this species, the baculum was located middorsally and was completely out of the bacular mound. The dorsal surface was marked by several longitudinal grooves that gave it a rough appearance (Fig. 3K).

The baculum was observed in nearly all analyzed specimens, except for $E$. perotis, where only two out of five specimens presented with a baculum. In all individuals that had a baculum, the baculum varied in both size and morphology (Fig. 3C, F, I and L). E. glaucinus and E. bonariensis had the largest sizes $(0.54 \mathrm{~mm}$ and $0.4 \mathrm{~mm}$, respectively), while $E$. auripendulus and $E$. perotis had the smallest sizes $(0.27 \mathrm{~mm}$ and $0.08 \mathrm{~mm}$, respectively).

In relation to morphology, in E. bonariensis, E. glaucinus and $E$. perotis, the baculum was concave in ventral region (Fig. 3F, I and L), and in E. auripendulus, it was rectilinear, with a rounded basis and an asymmetric tip that was larger on one side (Fig. 3C). In E. bonariensis, the baculum had a large, rounded base, tapering toward the apex and terminating at a sharp tip. Viewed laterally, it was concave in ventral region (Fig. 3F). In E. glaucinus, the baculum had a comma morphology when viewed laterally and rectilinear when seen dorsally or ventrally (Fig. 3I). In E. perotis, the baculum was extremely small, appearing to have square morphology (Fig. 3L).

\subsubsection{Genus Molossops (Peters, 1865)}

Average length of $M$. temmninckii's glans was $2.26 \mathrm{~mm}$. Equitability of its parts gave it a rectangular morphology, although it had distal grooves and furrows with folds that gave it a digitiform appearance (Fig. 2G and H). The glans was composed of three lobes: one dorsal and two latero-ventral lobes. On the ventral surface there was a deep central cleft, the urinary meatus, which separated the two latero-ventral lobes. This cleft ran approximately two-thirds of the ventral surface, which consequently exhibited a digitiform appearance (Fig. 2G).

The dorsal surface had two paired and larger lateral furrows that ran the entire length of the glans, and two smaller central paired furrows, which extended only in the final third of the glans, separating the dorsal lobe from the lateral lobes (Fig. $2 \mathrm{H}$ ).

The glans surface was covered with small epithelial projections, broader at the base and narrower at the apex; facing the proximal region, similar to those described for Cynomops species. No baculum was observed inside the glans.

\subsubsection{Genus Molossus (E. Geoffroy Saint-Hilaire, 1805)}

The glans of $M$. molossus and $M$. rufus were similar, presenting an average length of $5.59 \mathrm{~mm}$ and $4.47 \mathrm{~mm}$, respectively. They had conical morphology: a broader base tapering to the trilobed apex. The apex was divided into three lobes: a central lobe and two lateral lobes (a left one and a right one) (Fig. 3M-P). The central lobe had a median crest on its dorsal surface and the bacular mound on its ventral surface (Fig. 3MP).

The glans was rounded at the base, and on its dorsal surface, approximately $1 / 3$ of its length, there was a deep V-shaped furrow, the middorsal furrow. This furrow widened distally and surrounded the subapical portion of the glans toward the ventral surface, where it formed, together with the terminal portion of the accessory cavernous bodies, the urinary meatus' border (Fig. 3M-P).

The middorsal furrow presented in the midline of its interior a small median crest, which ran its entire length reaching the trilobed portion of the glans (Fig. 30 and P). From this point, the median crest became thicker and formed the aforementioned central lobe crest. In both species the crest had a median row of spiniform epidermal projections (Fig. $3 \mathrm{O}$ and P). Additionally, at the middorsal furrow level, the median crest was surrounded by two paired wrinkles that ran through the median-terminal portions of the furrow (Fig. 30 and P). 


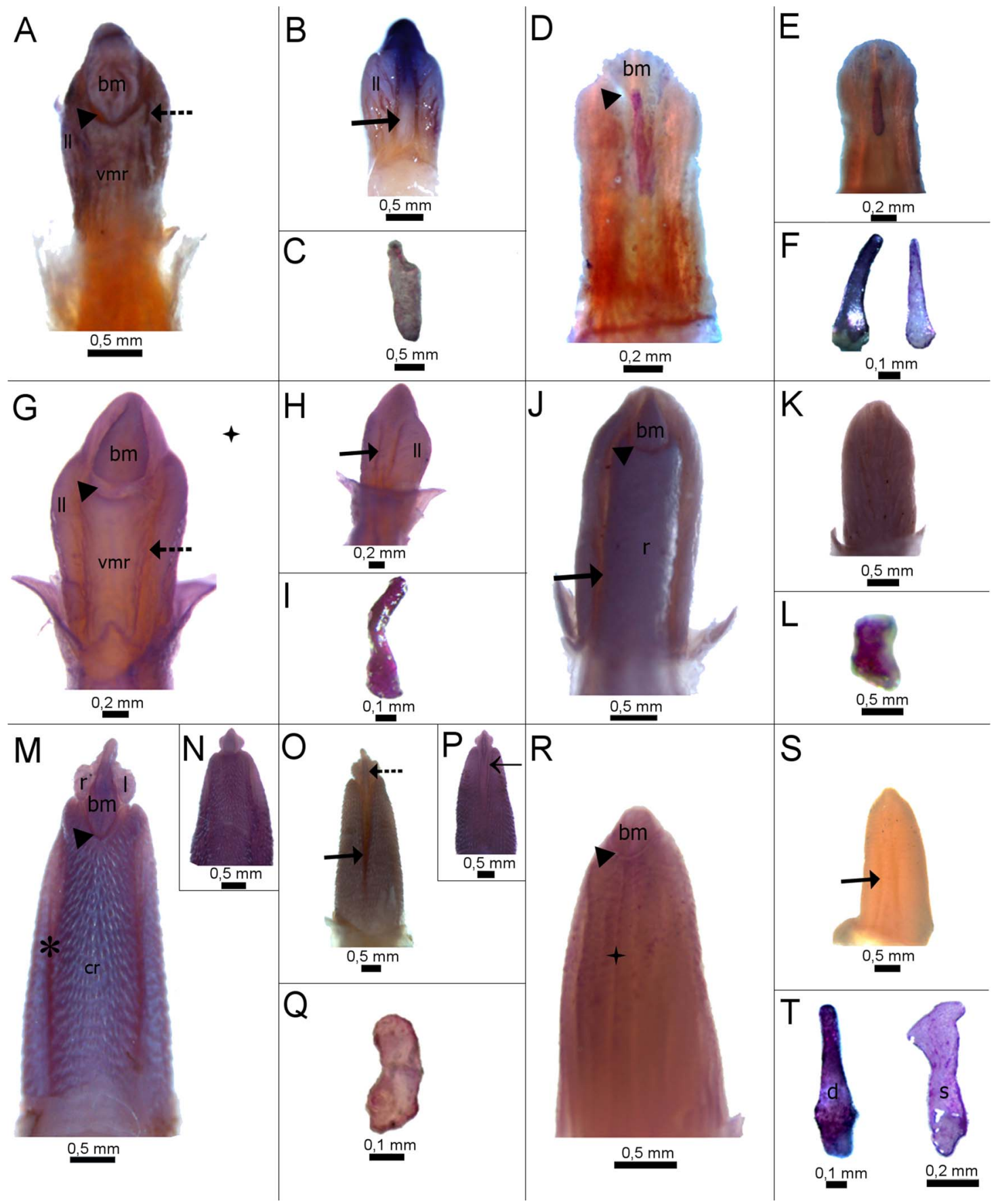

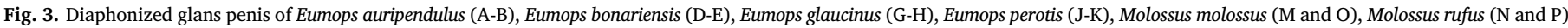

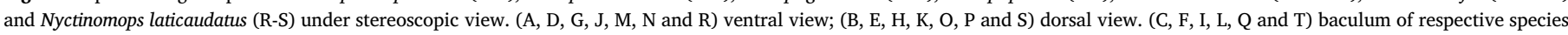

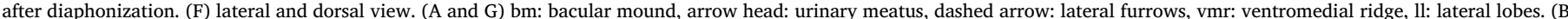

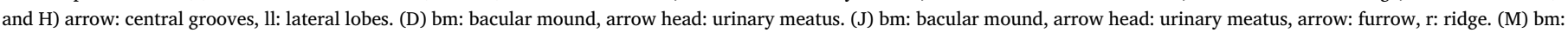

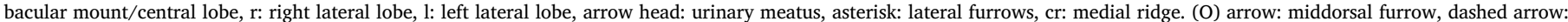

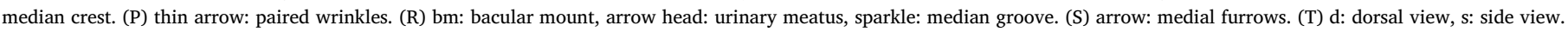

The ventral surface of the glans had two deep lateral furrows that ran throughout its length until the urinary meatus. At midpoint, a cylindrical medial ridge contained the urethra and corpus spongiosum. This ridge ran through the central portion to the meatus, where the urethra was externalized (Fig. $3 \mathrm{M}$ and N). Externally, the glans was covered by spiniform epidermal structures arranged in rows along the entire length of the glans. Only the inside of the middorsal furrow and the bacular mound did not have these projections.

Both species had a baculum, which was located in the central lobe or bacular mound. Its bone structure had similar morphology in both species, its ends were wider and rounded, and its middle was narrower. They had average lengths of $0.26 \mathrm{~mm}$ in $M$. molossus and $0.24 \mathrm{~mm}$ in $M$. rufus (Fig. 3Q).

\subsubsection{Genus Neoplatymops (Peterson, 1965)}

Neoplatymops mattogrossensis had the smallest glans, approximately $1 \mathrm{~mm}$ in length, with a triangular morphology. Similar to the other species, it was externally clotted by small, spiniform epidermal projections (Fig. 2I and J).

The dorsal surface (Fig. 2J) was marked by a deep middorsal 
furrow, which extended almost the entire glans length, dividing it into two equal parts. These parts were distally divided by small dorso-lateral folds that gave a digitiform appearance to the glans tip. The middorsal furrow extended to the ventral surface, where it expanded toward the sides of the glans resulting in a deep mid-ventral cleft, the urinary meatus. This cleft had in its interior a midventral projection with lanceolate form that was devoid of epidermal projections (Fig. 2I). As seen in Cynomops and M. temminckii species, no bone structure was observed inside the glans.

\subsubsection{Genus Nyctinomops (Miller, 1902)}

Nyctinomops laticaudatus' glans had an average length of $2.73 \mathrm{~mm}$, and its base was wide, tapering toward the apex. Similar to that found in Molossus species, the glans of $N$. laticaudatus had a conical morphology; however, unlike these, the distal region of the glans was not trilobulated, represented only by a rounded bacular mound (Fig. 3R and S). Externally, the glans was covered with small and scattered spiniform epidermal projections, similar to those found in other species already described, which were absent only in the bacular mound and the urinary meatus (Fig. 3R and S).

Ventrally, the glans had several longitudinal grooves, the median groove being the deepest. In the subapical region, there was a circular slit surrounding the entire ventral portion, the urinary meatus, which divided the glans into two parts: a larger one below and a smaller rounded one above additionally called the bacular mound (Fig. 3R). Dorsally, the glans was marked by a pair of medial furrows, which ran the entire length of the glans (Fig. 3S).

Inside the apical portion of the glans was the baculum, which had an average length of $0.64 \mathrm{~mm}$. Only the end of the baculum lay on the bacular mound. Bacular morphology was complex and difficult to describe. When viewed sideways (s) it was narrow and rectilinear up to two-thirds of its length, widening laterally and projecting to the ventral region in the remaining third. When viewed dorsally (d) or ventrally it had an arrow shape with a triangular base and a rectilinear middle and apex (Fig. 3T).

\section{Internal penile morphology}

Penises of eight analyzed species presented a vascular penis, including two main erectile tissues present. Distinct from the pattern in mammals, where the two main erectile tissues found were corpora cavernosa and accessory cavernous body, a third erectile tissue was also observed. All glans had these three erectile tissues: corpus spongiosum, corpora cavernosa (with respective tunicae albugineae) and the accessory cavernous body. Glans of all species were surrounded by a thin, non-vascularized and retractile prepuce. Despite the similarities, organization and presence of these tissues varied among species.

C. planirostris' and M. temminckii's prepuce had a keratinized epithelium externally and internally, and presented little pigmentation, which appeared in greater quantity in C. planirostris.

Both species had similarities in penis morphology. The glans was covered by a thick layer of keratinized epithelium, which gave rise to small spiniform projections, (wider at the base and sharpened at the apex (Fig. 4). The cavernous bodies were not very developed in these species and had a differentiated localization: ventrally in $C$. planirostris and latero-dorsally in M. temminckii (Fig. 4A-D). More proximal portions of the glans cavernous bodies were close, separated only by septa of tunica albuginea. However, in C. planirostris, there was only one septum, and in M. temminckii, the number of septa ranged from one to three (Fig. 4A and B). As the cavernous bodies extend to the intermediate and more apical portions of the glans, they were completely separate (Fig. 4C and D). The cavernous bodies of $M$. temminckii's penis presented greater development when compared with the C. planirostris' penis, as evidenced by the area occupied in the penis (Fig. 4A-D).

The corpus spongiosum in both species was restricted to a small tissue layer around the urethra. In addition, it was surrounded by a tunica albuginea, which was thicker and more defined in the cavernous bodies than in the corpus spongiosum (Fig. 4A-D). The tunica albuginea was composed of a well-defined layer of non-patterned, dense connective tissue and smooth muscle fibers.

In addition to cavernous bodies and corpus spongiosum, we observed a third type of erectile tissue, the accessory cavernous tissue, located dorsally and/or bilaterally to the tunica albuginea of the corpora cavernosa in the whole extension of the glans, composing alone the more apical portions. This tissue was different from the other tissues because it did not have a surrounding tunica delimiting its contours (Fig. 4). The erectile constitution of this tissue was confirmed by staining with Masson Tushmann's blue, which identified the smooth muscle cells surrounding the venous trabeculae. No bone or cartilaginous structure was observed in the glans of these species. The urethra consisted of transitional stratified epithelium and covered a large part of the glans length, exteriorizing at the urinary meatus.

The three species of Eumops analyzed (E. bonariensis, E. glaucinus and E. perotis) had similar patterns of tissue organization. The prepuce had many pigmentary cells, especially in E. perotis, and the glans epithelium had a low amount of keratin. The corpus spongiosum was underdeveloped, a pair of corpora cavernosa was dorsally observed and there was less quantity of accessory cavernous tissue. This tissue was found mainly in the most apical portions of the glans (bacular mound) (Fig. 5).

The corpora cavernosa and the corpus spongiosum were surrounded by a tunica albuginea that was thinner in the corpus spongiosum than in the corpora cavernosa. One septum divided the corpora cavernosa throughout the glans. In addition, it was noteworthy that a pair of nerves was present in the species, dorso-laterally arranged in the lateral lobes observed in the external morphology.

The baculum was present in all specimens of E. glaucinus and $E$. bonariensis and in only one of the two adult $E$. perotis specimens analyzed for histology (Fig. 5F). The juvenile E. perotis specimen had no baculum. The baculum was located dorsally in relation to the urethra and apical to the corpus cavernosum above this feature (Fig. 5B, D and F). In E. perotis, it was additionally possible to observe various cartilaginous cells just above the corpora cavernosa and before the baculum (Fig. 5F). The urethra was ventral, consisting entirely of transitional epithelium. It ran through the entire extension of the glans and externalized to the level of the urinary meatus.

Species M. molossus, M. rufus and N. laticaudatus shared the same penile tissue arrangement. The prepuce had the same characteristics observed in the previous species: thin, retractile, with few pigmentary cells and both epithelia (internal and external) keratinized. The glans epithelium had a thick layer of keratin, which formed the spiniform epidermal projections present in these species (Fig. 6).

The corpora cavernosa were dorsal and well developed, filling most of the dorsal portion of the glans. They were surrounded by a thick tunica albuginea and extended for almost the entire glans length; however, they were not present in the trilobulate glans tip in Molossus and in the bacular mound in Nyctinomops (Fig. 6G-I). One or two septa of the tunica albuginea divided the corpora cavernosa in the proximal region of the glans (Fig. 6A and B) and two septa divided in the intermediate region of the glans (Fig. 6D and E). In N. laticaudatus the corpora cavernosa were divided only by one septum in the entire extension of the glans (Fig. 6C and F).

The corpus spongiosum was less developed than the corpora cavernosa, and located ventrally and surrounding the urethra. Its tunica albuginea had similar constitution to the tunica of the cavernous tissue; however, it was noticeably thinner (Fig. 6A-F). The corpus spongiosum was present for most of the glans penis, being absent only after the urinary meatus when the urethra was externalized.

As in the other species, the accessory cavernous tissue was present throughout the glans extension. It was involved dorsally in more basal portions and formed two tissue masses on the lateral and intermediate portions of the glans, returning to join at the most apical portion. 

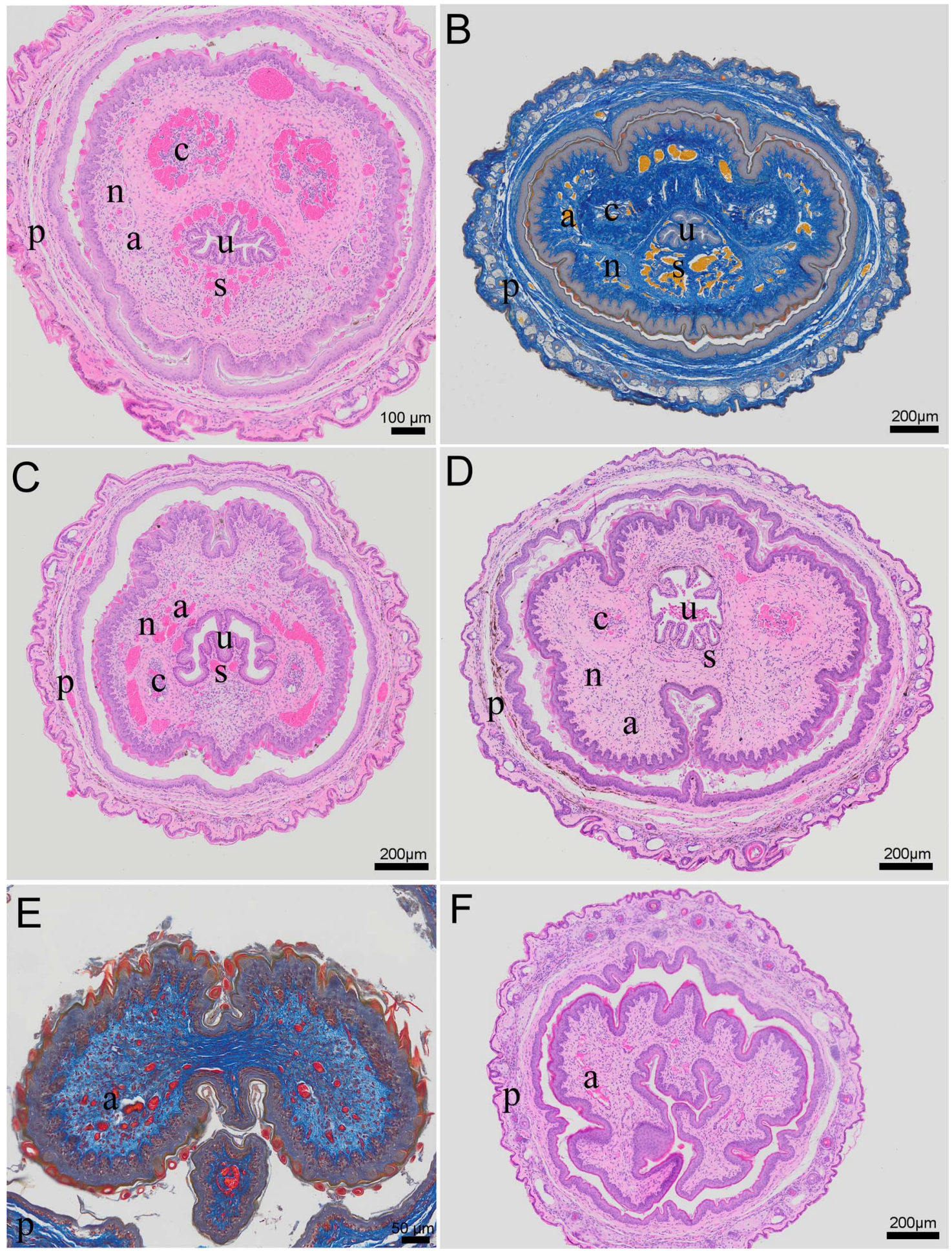

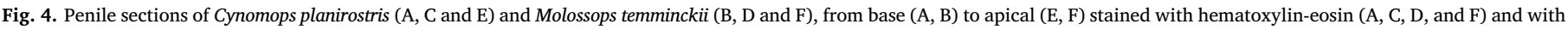
Masson Thusmann's blue (B and E). Abbreviations: p: prepuce, n: nerve, c: corpus cavernosum, s: corpus spongiosum.

Additionally, the urethra was constituted of transitional stratified epithelium and covered a large part of the glans length, externalizing at the urinary meatus level, the subapical level in the ventral surface of the penis (Fig. 6).

The location of the baculum was confirmed. In Molossus species, it was completely in the bacular mound, the central lobe in the trilobular terminal tip of the glans (Fig. $6 \mathrm{G}$ and H), and in N. laticaudatus it was in the last apical third of the glans, with only the tip of the baculum in the bacular mound (Fig. 6I). The baculum was essentially bony, had no medullary canal, and had a thick, well-defined periosteal layer around it. It was surrounded by the accessory cavernous tissue.

Table 1 summarizes the main macro- and micro-anatomic characteristics observed in the penis of the species.

\section{Discussion}

The penises of the bat species analyzed in this study have the general pattern observed in mammals, which easily recognizes two parts: 

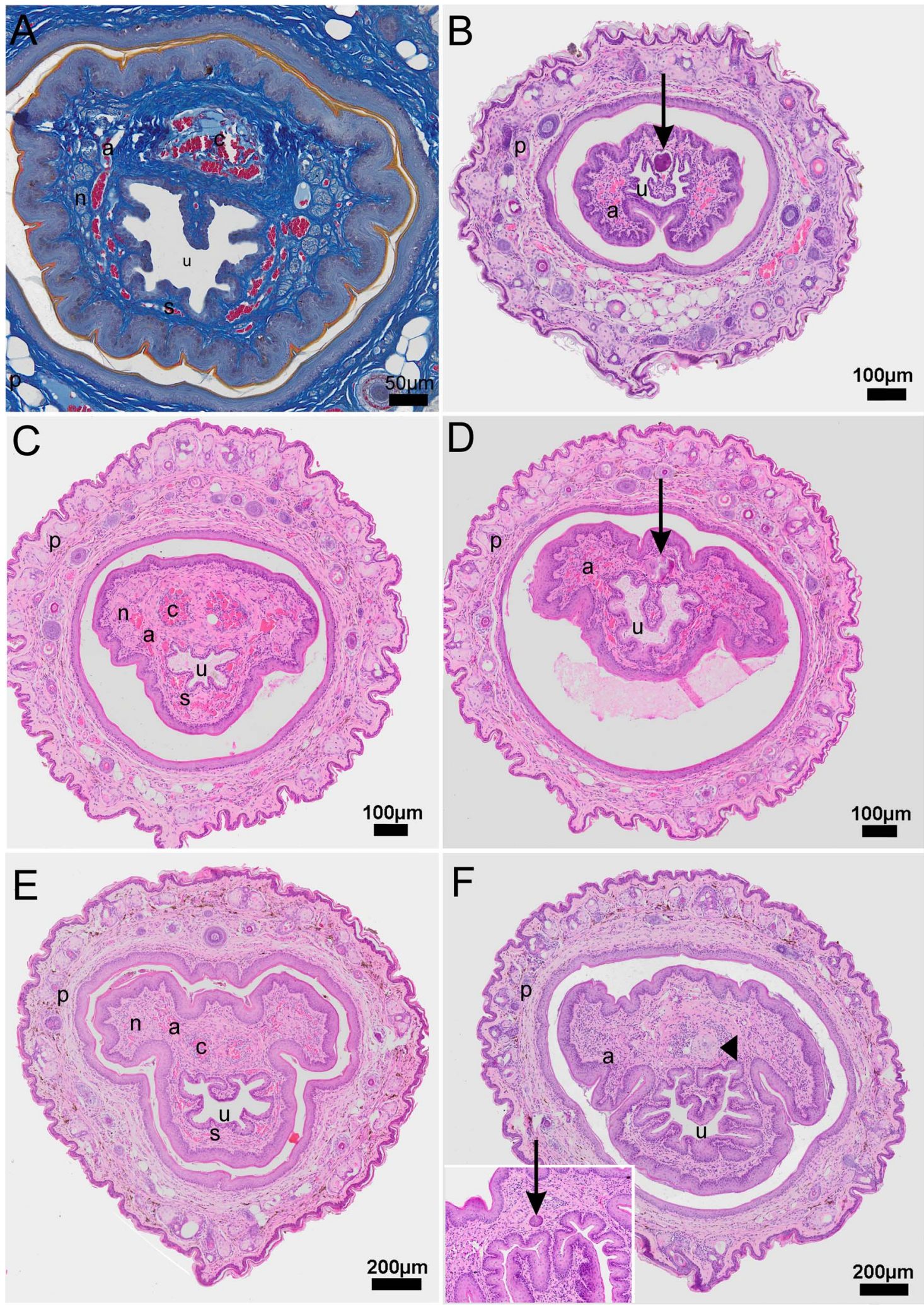

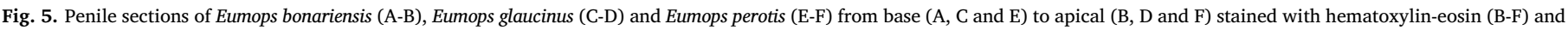

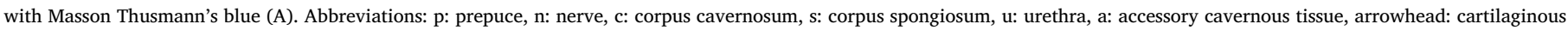
cells, arrow: baculum.

body and glans. In agreement with literature data for most of these species (Ryan, 1991a, 1991b), the glans is well developed and has spiniform epidermal projections; the prepuce consists of a thin, poorly vascularized sheath of tissue retractable covering the entire pendulous portion of the penis. This pattern is in contrast to that observed in Vespertilioniformes in which the glans is reduced and simple, and the prepuce is thick, glandular and highly vascularized (Matthews, 1937, 1941; Comelis et al., 2015). 

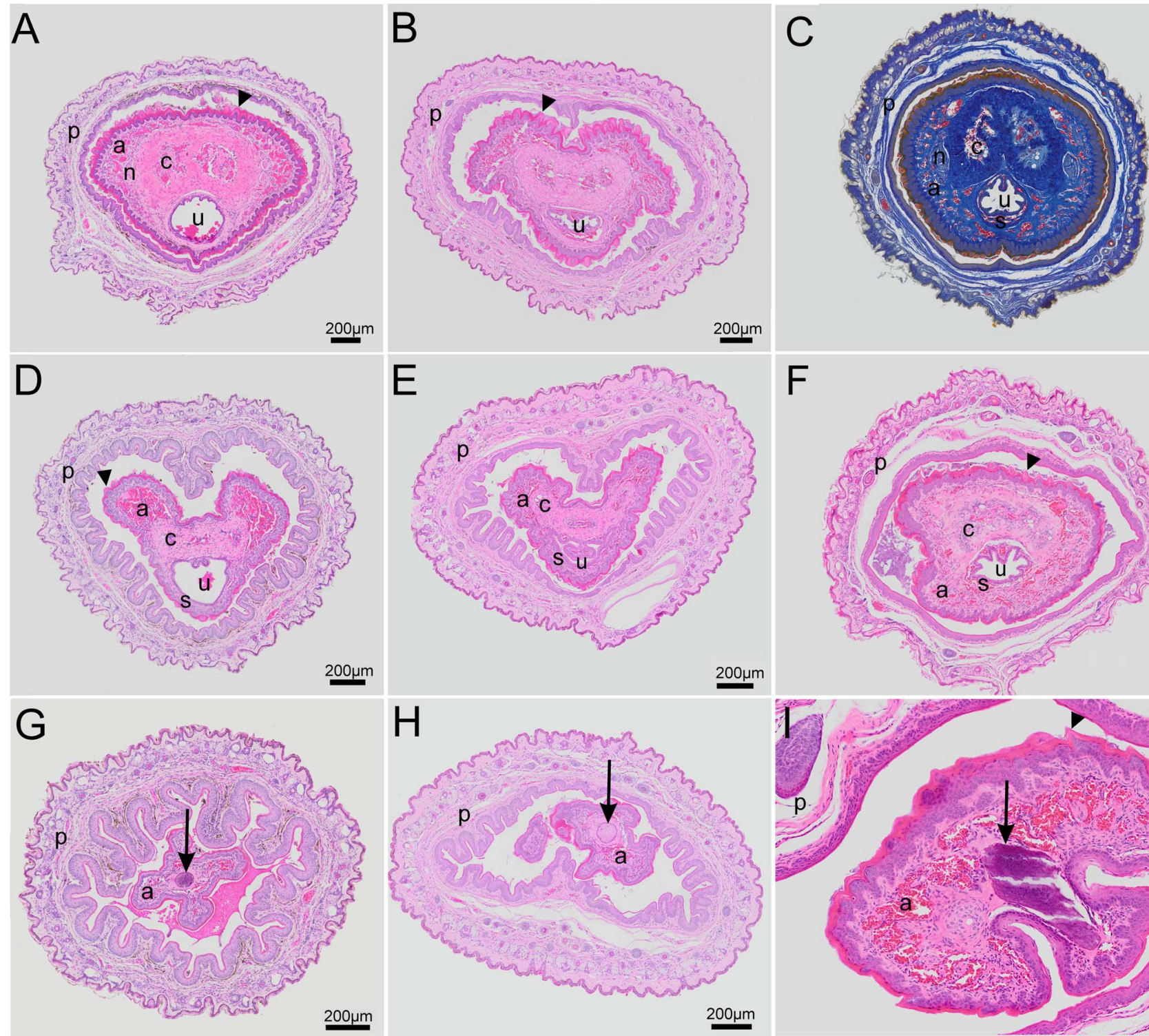

$200 \mu \mathrm{m}$
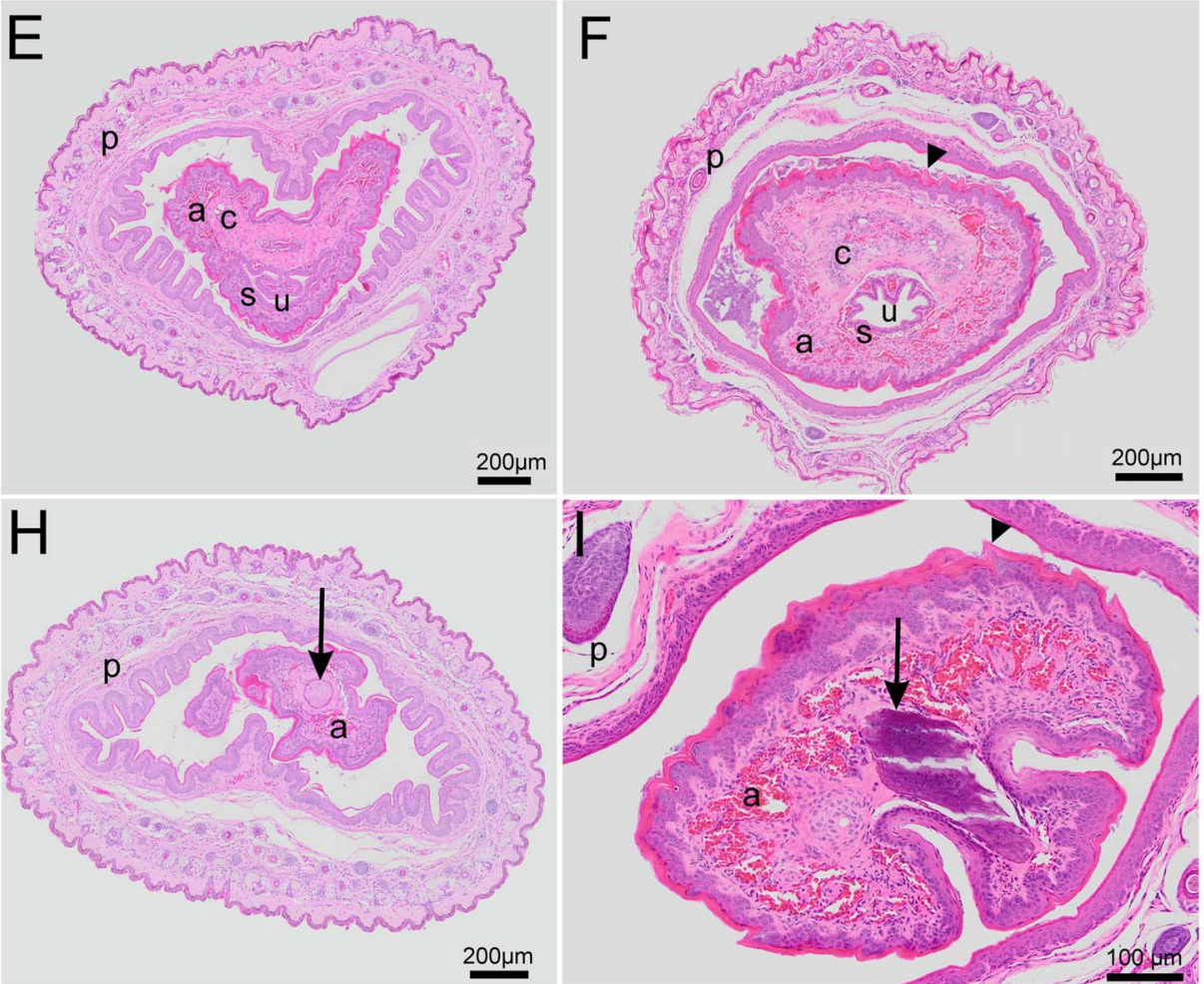

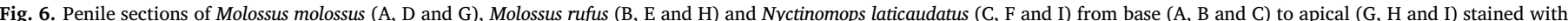

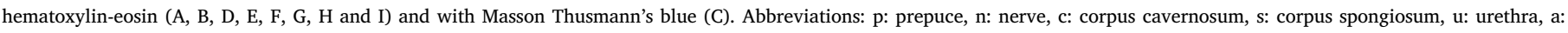
accessory cavernous tissue, arrow head: epithelial projection, arrow: baculum.

Table 1

Summary of the conditions of the main penile characteristics analyzed for each species.

\begin{tabular}{|c|c|c|c|c|c|c|c|}
\hline Taxon & Urethra & Corpus spongiosum & Corpora cavernosa & Number of corpora cavernosa & Accessory cavernous tissue & Baculum & Spines \\
\hline C. abrasus & - & - & - & - & - & absent & present \\
\hline C. planirostris & central & undeveloped & Undeveloped & 2 & highly developed & absent & present \\
\hline E. auripendulus & - & - & - & - & - & present & absent \\
\hline E. bonariensis & ventral & undeveloped & developed & 2 & undeveloped & present & absent \\
\hline E. glaucinus & ventral & undeveloped & developed & 2 & undeveloped & present & absent \\
\hline E. perotis & ventral & undeveloped & developed & 2 & undeveloped & absent/present & absent \\
\hline M. temminckii & central & undeveloped & undeveloped & $2-4$ & highly developed & absent & present \\
\hline M. molossus & ventral & undeveloped & developed & $2-3$ & developed & present & present \\
\hline M. rufus & ventral & undeveloped & developed & $2-3$ & developed & present & present \\
\hline N. mattogrossensis & - & - & - & - & - & absent & present \\
\hline N. laticaudatus & ventral & undeveloped & developed & 2 & developed & present & present \\
\hline
\end{tabular}

Based on the predominance of erectile and/or connective tissue in the mammalian penis, Wrobel and Bergmann (2006) classified it into three types: vascular (prevalence of erectile tissues), fibroelastic (prevalence of fibroelastic tissues), and intermediate (without prevalence of one tissue over the other). Penises of the analyzed specimens are vascular, a condition that appears to dominate among mammalian species previously analyzed (Kamikawa-Miyado et al., 2005; Yiee and Baskin, 2010; Rossi et al., 2012).

The vascular penis is characterized by the presence of two cavernous bodies and a corpus spongiosum of the urethra. However, bat 
species have variations in number and arrangement of these tissues as well as great variation in glans morphology and the presence and morphology of the baculum (Harrison and Matthews, 1937; Wimsatt and Kallen, 1952; Krutzsch, 1975; Krutzsch et al., 1976; Krutzsch and Crichton, 1987; Ryan 1991a, 1991b; Armstrong, 2005; Hoofer et al., 2006; Herdina et al., 2010; Comelis et al., 2015).

Nine species histologically analyzed presented three erectile tissues: two main ones - considered by their development and representation in the glans. These were the corpora cavernosa and the accessory cavernous tissue, which made up the bulk of the penis; and a secondary, less developed erectile tissue, represented only by a thin tissue mass with few cells of extension around the urethra, the corpus spongiosum of the urethra. Although species shared these conditions, they displayed differences in number and arrangement of the corpora cavernosa and the quantity and location of accessory cavernous tissue.

With little mass variation, the corpora cavernosa differed mainly in location. In C. planirostris and M. temminckii, the corpora cavernosa showed the lowest level of development and its location- ventral and lateral-dorsal, respectively, were the most distinguished. The corpora cavernosa were observed fused in the basal portions, where they were only separated by septa of the tunica albuginea and completely separated in more apical portions. Unlike these species, in the Eumops and $N$. laticaudatus species, the two cavernous bodies, arranged dorsally, remained fused and individualized by one septum of the tunica albuginea throughout the glans. In the Molossus species, due to the variation in the number of septa, two cavernous bodies were found in the most basal part of the penis, three in the intermediate portions, and one in the apical portions. These bodies were always located in the dorsal region of the penis.

Accessory cavernous tissue varied in both mass and location. In the specimens of $M$. temminckii and C. planirostris, it occupied most of the glans in more basal portions and the whole glans in the apex. For the specimens of M. molossus, M. rufus and N. laticaudatus, accessory cavernous tissue was concentrated in the dorsal region of the glans. In the specimens of E. bonariensis, E. glaucinus and E. perotis where accessory cavernous tissue appeared in a smaller quantity, it was observed in the sides, along with the nerves, forming the lateral lobes and, in the most apical portion, the bacular mound. This tissue does not occur in all mammalian species, and had been observed in other species of Chiroptera and in some Eulipotyphla (Insectivora) (Rauther, 1903; Matthews, 1937, 1941; Wimsatt and Kallen, 1952; Ercolani, 1868; Smith and Madkour, 1980; Ryan, 1991a, 1991b; Kamikawa-Miyado et al., 2005).

Despite this tissue's denomination, its origin and functions have not been fully determined and it is not studied in Chiroptera. Studies showed that penile cavernous accessory tissue appears to exhibit no relationship or homology with cavernous tissue (Wimsatt and Kallen, 1952). Additionally, the proposal of Wimsatt and Kallen (1952), that this accessory tissue may have a similar origin to that observed in some insectivores, in which it arose as a result of the independent vascularization of subcutaneous tissues that surrounded erectile bodies through the branches of the dorsal penile arteries, has not yet been determined.

Our results corroborate the erectile nature of this tissue that it is rich in smooth muscle cells, a condition already noted by us in a previous study of the penis of the vespertilionid Eptesicus furinalis. In this species, this tissue is responsible for the characteristic enlargement of the penis viewed externally under a stereoscopic microscope (Comelis et al., 2015).

Unlike the condition observed in some genera of vespertilionid bats (Herdina et al., 2010; Comelis et al., 2015) where the corpora cavernosa are not part of the glans (which contains mostly accessory cavernous tissue) and for humans who do not have accessory tissue in the penis (Yiee and Baskin, 2010), both corpora cavernosa and accessory cavernous tissue are present in the glans penis of all species of molossids analyzed thus far, except for Moormopterus planiceps where Krutzsch and Crichton (1987) were unable to find this tissue. This fact supported the Smith and Madkour (1980) proposition that the absence or reduction of these tissues in bats is a derived condition.

The poorly developed corpus spongiosum, limited to a small band around the urethra, appears to be typical of Molossidae family members (Matthews, 1941; Ryan, 1991a, 1991b). There was variation in the degree of this tissue's prevalence among the taxa, and the species of Eumops and M. temminckii showed the greatest volume. Considering the high proportion of this tissue in humans, Smith and Madkour (1980) interpreted the low proportion of corpus spongiosum as being a basal characteristic for the Chiroptera group.

When comparing results of the evaluated Molossidae taxa with those of Vespertilionidae already analyzed (Wimsatt and Kallen, 1952; Comelis et al., 2015; Herdina et al., 2015a,b), we found that this condition was additionally observed for some vespertilionid taxa. However, data for Eptesicus furinalis revealed that the penis corpus spongiosum is well developed in this taxon (Wimsatt and Kallen, 1952; Comelis et al., 2015), indicating that there is, in this family and more specifically in this taxon, a derived condition for this character.

Spiniform morphology of epidermal projections present in the glans was shared by seven of the 11 analyzed species (C. abrasus, C. planirostris, M. temminckii, M. molossus, M. rufus, N. matogrossensis and $N$. laticaudatus), varying only in size and distribution along the glans. Their presence has already been reported for these and other species of molossid and vespertilionid bats (Ryan, 1991a, 1991b; Cryan et al., 2012). Because it is a shared characteristic by most molossid taxa, it was considered basal for Chiroptera (Aronson and Cooper, 1967; Sachs et al., 1984; Krutzsch and Crichton, 1987; Ryan, 1991a, 1991b; Kelly, 2000). However, it is not a shared condition by all families because they were not observed in most of the Vespertilionidae and Miniopteridae specimens analyzed until now (Wimsatt and Kallen, 1952; Ryan, 1991a, 1991b; Comelis et al., 2015), and even in some species of molossids, for example, the Eumops species of the present work. Absence of projections on the glans of E. auripendulus, E. bonariensis, E. glaucinus and E. perotis note a derived condition for this character in these taxa.

Epidermal or genital spines occur in other mammals such as primates, rodents, carnivores, and insectivores (Aronson and Cooper, 1967; Lidicker and Yang, 1986; Ryan, 1991a, 1991b; Stockley, 2002; Kamikawa-Miyado et al., 2005; Silva et al., 2013), where they vary greatly in morphology and size. They are not restricted to mammals, additionally occurring in other groups of animals such as insects, snakes and waterfowl (Waage, 1979; Rönn et al., 2007; Friesen et al., 2014).

The role of these structures lining of the mammalian penis has been evaluated in certain groups. Variations in androgen hormone concentrations, especially testosterone, are associated with the development and growth of these projections. These studies showed that the increase in testosterone serum levels caused growth and appearance of these structures, while a decrease caused their disappearance (Aronson and Cooper, 1967; Dixson, 1991; Stockley, 2002; Hosken and Stockley, 2004; Armstrong, 2005).

Cryan et al.ös (2012) study demonstrated for the first time in Chiroptera the occurrence of spines in the glans of vespertilionids $L a$ siurus cinereus and L. borealis. In these species, two general types of penile spines were observed: a longer, slender spine that emerged from the lateral aspects of the glans penis and a shorter, thicker spine that was more evenly distributed across the dorsal and lateral surfaces of the glans. The authors observed a seasonal increase in the prevalence and length of these spines, which was coincident with testes regression and growth of accessory glands. Despite the atrophied testes, Leydig cells continued to secrete sufficient quantities of androgen to maintain libido, ensuring that mating occurred after testes recrudescence due to spermatozoa that are stocked in the caudae epididymides. One hypothesized function of penile spines in Lasiurusis is that they serve as copulatory lock during aerial mating.

Other hypothesized functions of penile spines in mammals are for sensory feedback during copulation, participation in the prolongation of coupling by swelling producing a coital lock, stimulation of the 
female reproductive tract inducing ovulation, or the removal of a copulatory plug pre-deposited in the female reproductive tract (Aronson and Cooper, 1967; Sachs et al., 1984; Krutzsch and Crichton, 1987; Kelly, 2000; Orr and Brennan, 2016). In vespertilionid bats where no projections were observed on the epithelium of the glans, some authors attributed the thick prepuce to aid in these actions (Ryan, 1991b; Comelis et al., 2015).

In association with histomorphological characters of the penis with important functions in the copula, evolutionary interpretations additionally include the os penis or baculum. The baculum showed to be an important evolutionary character to be considered because it presents variability within the family, either by its presence or absence, and if present, by its morphology.

The os penis was identified macro- and microscopically inside the glans penis of the species $M$. molossus, $M$. rufus, $N$. laticaudatus, $E$. auripendulus, E. bonariensis, E. glaucinus and E. perotis, and was absent in the species of C. planirostris, C. abrasus, M. temminckii and N. matogrossensis. Its morphology was quite varied, especially between the genera, although it additionally varied within the genus. The bacula of the two species of Molossus were the most similar, while the species of Eumops had the greatest variability; the greater similarity was between E. glaucinus's and E. bonariensis's os penis. In addition, sizes of the bacula varied; the smallest was observed for $E$. perotis and the largest for N. laticaudatus.

Another interesting condition regarding the baculum was observed in $E$. perotis where five (four adults and one juvenile specimens) of the eight analyzed specimens did not have os penis. Brown (1967), when analyzing specimens of $E$. perotis did not find a baculum inside the penis.

Development of the baculum is thought to be mainly due to androgens, with evidence in rats, that androgen and locally aromatized estrogen played a direct role in the early development of the baculum (Yonezawa et al., 2011). Measurements of plasma testosterone levels during the life cycle of rats indicate that it did not correlate with the growth curve of the baculum, which reaches its maximal growth rate with rather low plasma testosterone levels (Yonezawa et al., 2011). In addition, by accompanying the development of the baculum, which is constituted of three developmentally distinct parts, was verified that the proximal and central portions fuse and begin to ossify within five days of birth, and elongated dramatically in the postnatal-to-juvenile period. In contrast, the distal portion does not ossify until puberty when it lengthened greatly and completely formed (Kelly, 2000; Yonezawa et al., 2011).

In bats, patterns of baculum development were studied in four vespertilionid species, Nyctalus noctula, Vespertilio murinus, Eptesicus serotinus, Pipistrellus pipistrellus, and one species of Pteropodidae, Cynopterus brachyotis (Smirnov and Tsytsulina, 2003; Herdina et al., 2016). The results showed that species have different patterns of ossification. In newly born noctule bats ( $N$. noctula) the baculum is small and cartilaginous and remains thus up to second or third day after birth. It ossifies completely by about the seventh day and has its definitive shape around age of one month, when young bats are able to fly. It reaches a definite size and shape at the age of about one year (Smirnov and Tsytsulina, 2003). These data show that the baculum is already present in the young, even though it has not yet reached the definitive size.

Based on these data and in fact that four of our specimens of $E$. perotis without baculum were adults, we assume that Brown (1967) probably only analyzed specimens of $E$. perotis without baculum. This variation in the presence of the os penis in E. perotis, along with the morphological variation exhibited by Eumops species, reflects an apparent species-specific condition for this taxon. Based on these results, it is possible to infer that the baculum in E. perotis is under selective pressure and that it may be lost or disappear in the future.

Facts like this have promoted extensive discussions among scholars on the functional relevance of the baculum. Burtös proposal (1936) that the bone is a pleiotropic artifact of penile development was strongly rebounded by Patterson and Thaeler (1982) and lost strength when other studies provided evidence that the baculum is subject to direct selection and therefore has an adaptive, functional role in copulation (Ramm, 2007; Yonezawa et al., 2011; Stockley, 2012). The presence and the absence of baculum in different molossid species, as well as its presence and absence in the specimens of $E$. perotis, constitute evidence that the baculum is adaptive. The ways in which males benefit from its presence and variation in size and shape have not yet been determined. Nevertheless is possible to assume that intra-sexual selection pressure (as polygamous or seasonal mating systems) is driving bacular evolution in bats.

The presence of cartilage at the site of the baculum, observed in the specimen of $E$. perotis, reinforces its origin by endochondral ossification, as proposed by Smirnov and Tsytsulina (2003). They analyzed the ontogeny of the baculum on Nyctalus noctula and Vespertilio murinus, two species of vespertilionid bats. However, other sources for the mammalian baculum and even bat baculum have been proposed. Some studies have noted an association between the development of the baculum and the cavernous body, suggesting that the baculum originates from ossification of the most distal portion of the cavernous body. Others suggest a more complex origin as reported by Kelly (2000) highlighting the studies of Glucksmann et al. (1976) and Murakami and Mizuno (1984), who noted that in rats and mice these two structures share the same mass of mesenchymal tissue during penis embryonic development. What has been common in studies with Chiroptera is the observation that the baculum is closely associated with cavernous tissue (Herdina et al., 2010, 2015a,b), which was additionally observed in this study.

Histomorphological analysis in the eight molossid species demonstrates that variations in the arrangement of penile tissues were directly related to the presence or absence of the baculum and glans morphology. The presence of accessory cavernous tissue had already been observed in the penis of these and other species of bats. In species where the structure was absent, there was a greater amount of accessory cavernous tissue throughout the glans, whereas in species where the baculum was present, there was less accessory cavernous tissue that was more concentrated in the apex.

Arrangement of cavernous bodies and variation in number of septa of its tunica albuginea were variable in the species, appearing to be directly related to the absence or presence of the baculum. In species with a baculum, the cavernous bodies were dorsally oriented; while in those that did not have the structure, their position was ventral or latero-ventral. In C. abrasus and M. temminckii, which lacked a baculum, the cavernous body occurred in a smaller quantity and was distributed in the basal and intermediate parts of the glans. However, in species with a baculum, the corpora cavernosa occurred in greater quantity and was concentrated in the dorsal region.

Herdina et al. (2015a,b), when analyzing the penile histomorphology and the functional potential of flaccid and 'erect' penises that were inflated with $10 \%$ formalin of three vespertilionid species that have a baculum (Pipistrellus pipistrellus, $P$. nathusii and Nyctalus noctula) by $\mu \mathrm{CT}$ and 3D reconstruction, were able to show that the baculum and corpus cavernosum form a functional unit to support both the penile shaft and the more distal glans tip increasing overall flexural stiffness of the glans and shaft of the penis during erection. Their results additionally support that the baculum protects the distal part of urethra and the external urethral orifice from compression during copulation. Our results reinforce these hypotheses.

In mammalian species that do not have a baculum, the penis works properly for efficient coupling. In humans, the corpus spongiosum appears to protect the urethral opening during copulation (Hatzichristou et al., 2003). In other mammals, this tissue, which functions as a low pressure system, can expand the glans sufficiently in such a way that in species without a baculum, the glans could assume the function of this structure as an element of stiffness (Purohit and Beckett, 1976; Holmes 
et al., 1991; Kelly, 2000). In bat species with accessory cavernous tissue in the glans, this function is optimized or additionally performed by this tissue.

It is possible to assume that, similar to the studies of Herdina et al. (2015a), experiments in the molossid species involving penile inflation could produce or reveal important information for the understanding of variations in penile morphology and tissues during erection. Despite the absence of these data, but using the information obtained in the present study, and literature data for species of bats and other mammals, it is possible to make some inferences about the functional role of tissues in the molossid penis.

We can infer that swelling of the penis in these species of molossid bats is dependent on the three erectile tissues and their representations in the penis. This would contribute differently in the process and success of copulation in these animals. Although not confirmed in the present study, it is possible to infer that in Cynomops and Molossops, the erection would be mainly due to the action of the accessory cavernous tissue, with less participation of the traditional erectile tissues because these are hardly represented. On the other hand, the opposite would occur in Eumops species, where the erection would occur mainly through traditional erectile tissues due to low embodiment of the accessory tissue in this genus. As for Molossus and Nyctinomops, the equivalence in the representation of these tissues in their penises would give them equal participation in the overall mechanism of erection.

Despite recognized variations in glans and baculum morphology in mammals, few studies have analyzed the effective capacity of these structures as distinctive elements between different hierarchical levels in Chiroptera (Brown et al., 1971; Hill and Harrison, 1987; Thomas et al., 1994; Armstrong, 2005; Douangboubpha et al., 2010; Herdina et al., 2010, 2014). This possibly occurred because some authors' hypotheses stated that although the baculum had a species-specific function in reproduction, with a possible role in reproductive isolation, its taxonomic implication would be restricted to species, and would have limited value at higher levels of classification (Howell, 1938; Marler, 1957; Callahan, 1976).

Current studies have demonstrated that characteristics of the glans and baculum, in addition to having an important role in the diagnosis of taxa, have supported clades formed in phylogenetic analyses using other morphological characters and molecular characters (Spitzenberger et al., 2006; Jacobs et al., 2013; Gregorin and Cirranello, 2016).

Our results provide evidence that, for the analyzed molossid taxa, except Eumops species, significant variations with taxonomic implications occurred among intergeneric species, agreeing with the works of Ryan (1991a, 1991b), which additionally evaluated species of other molossid genera.

Despite similarities in the composition and arrangement of penile tissues, especially the corpora cavernosa and accessory cavernous tissue of $C$. planirostris and M. temminckii, and although these species as well as $N$. matogrossensis had no baculum, it is possible to state that the different pattern of tissue organization in these species may be responsible for glans morphology. The greatest sharing of characteristics occurred between $C$. abrasus and C. planirostris. In the species M. temminckii and $N$. matogrossensis the glans was very different among themselves and from those of Cynomops.

These results reinforce the taxonomic hypothesis that Cynomops and Neoplatymops are not subgenera of Molossops. Results of the glans morphology analysis in the literature as well as of the present work constitute strong evidence that glans morphology promotes distinctiveness of the species of different genera (Peters et al., 2002; Gregorin and Cirranello, 2016).

For Eumops species, similar relationships of glans morphology reinforced information obtained by Gregorin and Cirranello (2016) in phylogenetic analyses using different morphometric characters for the same species as analyzed in our study. Of the four species analyzed the one that differed most with respect to glans morphology was $E$. bonariensis. In the study by Gregorin and Cirranello (2016), E. bonariensis appeared as a sister taxon of the clade consisting of another three species, E. auripendulus, E. glaucinus and E. perotis. This result was identical to that observed by Bartlett et al. (2013) and Medina et al. (2014) after analyzing molecular data of these and other species of Eumops.

It should be noted that, in spite of these species sharing glans morphology characteristics, it did not concur with baculum characteristics, which presented different morphologies. The highest similarities were between E. glaucinus and E. bonariensis. In Eumops, the baculum varied interspecifically, shown to be an important character in species differentiation.

Like Gregorin and Cirranello (2016), we cannot say anything regarding the relationship of $N$. laticaudatus to other species, and even to the genus, because it was the only species of the genus analyzed. However, it is possible to say that $N$. laticaudatus has a more similar glans morphology to Eumops species than to Molossus.

In relation to the species $M$. molossus and $M$. rufus, our results only reinforce the morphological similarity between these two Molossus taxa. This similarity additionally extends to many other features that are typically used in taxonomic studies, making it difficult in most cases to determine their precise identification (Morielle-Versute et al., 1996; Leite-Silva et al., 2003)

Regarding all taxonomic considerations, sexual selection is the main explanation used by several authors to explain variations in the mammalian baculum and glans morphology. They established that animals were subjected to sexual selection over the years to better adapt to the female reproductive apparatus, to the type of reproductive behavior of the species and to the level of competition by the female (Dixson, 1995; Harcourt et al., 1981; Patterson and Thaeler, 1982; Moller, 1988; Dahl et al., 1993; Dixson et al., 2004; Ramm, 2007).

Additional authors stated that such sexual selection could act through pre- or post-copulatory mechanisms (Hosken and Stockley, 2004; Ramm, 2007; Rowe and Arnqvist, 2011; Simmons, 2014). In the former, by the attraction of females and guarantee of copula (Bertin and Fairbairn, 2005; Langerhans et al., 2005), in the latter, through sperm competition and the female's critical choice for the male, to create "better genes" or "sexier sons" or more competitive offspring (Eberhard, 1985; Hosken and Stockley, 2004; Ramm, 2007).

This genital co-evolutionary process appears to be more intense in promiscuous species than in monogamous species, where the genital morphology evolves slowly (Arnqvist, 1998). Analyses in primates and non-feline carnivores revealed that the baculum tends to be larger and the genitalia more complex in species where females copulate with several males (Dixson, 1987; Verrell, 1992; Ferguson and Larivière, 2004). Similarly, in rodent species higher levels of sperm competition apparently favor the increase in penile length (Ramm, 2007).

The few analyses conducted for bats have not found a link between sperm competition and length of the baculum. This suggests the presence of multiple factors influencing genital evolution, and that the importance of each of them possibly varies between groups because the reproductive behaviors in bats are varied and still very little is known (Ramm, 2007). This emphasizes the need for detailed analyses involving males and females to better understand these processes.

Based on all findings, the results of the present study examining penis and baculum morphology in species of molossid bats reinforce the importance of these structures as a taxonomic feature in bat species and indicate that more studies are necessary to completely understand reproduction in bats and the baculum function.

\section{Acknowledgments}

The scholarships awarded to Manuela Tosi Comelis by the São Paulo State Research Foundation (FAPESP: 2012/24288-0 and 2015/069239) and the financial support from grants (2009/16181-9 and 2013/ 11859-2) from the São Paulo State Research Foundation (FAPESP) and 


\section{the Brazilian National Research and Development Council (CNPq - Processes 302008/2010-1 and 301073/2013-9) to EMV are gratefully acknowledged.}

\section{References}

Ammerman, L.K., Lee, D.N., Tipps, T.M., 2012. First molecular phylogenetic insights into the evolution of free-tailed bats in the subfamily Molossinae (Molossidae, Chiroptera). J. Mammal. 93, 12-28.

Armstrong, K.N., 2005. A description and discussion of the penile morphology of Rhinonicteris aurantius (Gray, 1845) (Microchiroptera: Hipposideridae). Austr. Mammal. 27, 161-167.

Arnqvist, G., 1997. The evolution of animal genitalia distinguishing between hypotheses by single species studies. Biol. J. Linn. Soc. 60, 365-379.

Arnqvist, G., 1998. Comparative evidence for the evolution of genitalia by sexual selec tion. Nature 393, 748-786.

Aronson, L.R., Cooper, M.L., 1967. Penile spines of the domestic cat: their endocrinebehavior relations. Anat. Rec. 157, 71-78.

Bartlett, S.N., McDonough, M.M., Ammerman, L.K., 2013. Molecular systematics of bonneted bats (Molossidae: Eumops) based on mitochondrial and nuclear DNA sequences. J. Mammal. 94, 867-880.

Baryshnikov, G.F., Olaf, R., Bininda-Emonds, P., Abramov, A.V., 2003. Morphological variability and evolution of the baculum (os penis) in Mustelidae (Carnivora). J. Mammal. 84, 673-690.

Benda, P., Tsytsulina, K., 2000. Taxonomic revision of Myotis mystacinus group (Mammalia: Chiroptera) in the Western Palearctic. Acta Soc. Zool. Bohem. 64, 331-398.

Benda, P., Reiter, A., 2006. On the occurrence of Eptesicus bobrinskoi in the Middle East (Chiroptera: Vespertilionidae). Lynx (Praha) 37, 23-44.

Benda, P., Kiefer, A., Hanák, V., Veith, M., 2004. Systematic status of African populations of long-eared bats, genus Plecotus (Mammalia: Chiroptera). Folia Zool. 53, 1-48 monograph 1.

Bertin, A., Fairbairn, D.J., 2005. One tool, many uses: precopulatory sexual selection on genital morphology in Aquarius remigis. J. Evol. Biol. 18, 949-961.

Brown, R.E., 1967. Bacula of some New World molossid bats. Mammalia 31, 645-667.

Brown, R.E., Genoways, H.H., Jones Jr., J.K., 1971. Bacula of some neotropical bats. Mammalia 35, 456-464.

Burt, H.W., 1936. A study of the baculum in the genera Perognathus and Dipodomys. J. Mamm. 17, 145-156.

Burt, W.H., 1960. Bacula of North American mammals: University of Michigan. Miscellaneous Publications of the Museum of Zoology 113, 1-75.

Callahan, J.R., 1976. Systematics and biogeography of the Eutamias obscurus complex (Rodentia: Sciuridae). Ph.D. Thesis. University of Arizona, Tucson. http://arizona. openrepository.com/arizona/bitstream/10150/289527/1/azu_td_7711452_sip1_m. pdf.

Cayetano, L., Maklakov, A.A., Brooks, R.C., Bonduriansky, R., 2011. Evolution of male and female genitalia following release from sexual selection. Evolution 65 2171-2183.

Comelis, M.T., Bueno, L.M., Góes, R.M., Morielle-Versute, E., 2015. Penile histomorphology of the neotropical bat Eptesicus furinalis (Chiroptera: Vespertilionidae). Zool. Anz. 258, 92-98.

Cotterill, F.P.D., 2002. A new species of horseshoe bat (Microchiroptera: Rhinolophidae) from south-central Africa: with comments on its affinities and evolution, and the characterization of rhinolophid species. J Zool. 256, 165-179.

Cryan, P.M., 2008. Mating behavior as a possible cause of bat fatalities at wind turbines. J. Wildlife Manage. 72, 845-849.

Cryan, P.M., Jameson, J.W., Baerwald, F.F., Willis, C.K.R., Barclay, R.M.R., Snider, A Crichton, E.G., 2012. Evidence of late-summer mating readiness and early sexual maturation in migratory tree-roosting bats found dead at wind turbines. PLoS ONE 7, e47586.

Dahl, J.E., Gould, K.G., Nadler, R.D., 1993. Testicle size of orangutans in relation to body size. Am. J. Phys. Anthropol. 90, 229-236.

De Knegt, L.V., Silva, J.A., Moreira, E.C., Sales, G.L., 2005. Morcegos capturados no município de Belo Horizonte, 1999-2003. Arq. Bras. Med. Vet. Zootec. 57, 576-583.

Dixson, A.F., 1987. Baculum length and copulatory behavior in primates. Am. J. Primatol. $7,51-60$.

Dixson, A.F., 1991. Penile spines affect copulatory behaviour in a primate (Callicthrix jacchus). Physiol. Behav, 49, 557-562.

Dixson, A.F., 1995. Baculum length and copulatory behaviour in carnivores and pinnipeds (Grand Order Ferae). J. Zool. 235, 67-76.

Dixson, A.F. 2012. Sexual Selection and Genitalic Evolution. In: Dixson, A.F. (Ed.) Primate Sexuality: Comparative Studies of the Prosimians, Monkeys, Apes and Humans. Oxford University Press, Oxford, pp. 334-378.

Dixson, A.F., Nyholt, J., Anderson, M., 2004. A positive relationship between baculum length and prolonged intromission patterns in mammals. Acta Zoolog. Sin. 50, 490-503.

Douangboubpha, B., Bumrungsri, S., Soisook, P., Satasook, C., Thomas, N.M., Bates, P.J., 2010. A taxonomic review of the Hipposideros bicolor species complex and H. pomona (Chiroptera: Hipposideridae) in Thailand. Acta Chiropterol. 12, 415-438.

Eberhard, W.G., 1985. Sexual Selection and Animal Genitalia. Harvard University Press, Cambridge.

Eberhard, W.G., 2001. Species-specific genitalic copulatory courtship in sepsid flies (Diptera, Sepsidae, Microsepsis) and theories of genitalic evolution. Evolution 55, 93-102.
Eger, J.L., 1977. Systematics of the Genus Eumops (Chiroptera: Molossidae). Life Sci. Contrib. 110, 1-69.

Ercolani, G.B., 1868. Dei tessuti e degliorganicrittili. Mem. Dell'Accad. Dell. Scienze. 2, 281-362.

Ferguson, S.H., Larivière, S., 2004. Are long penis bones an adaption to high latitude snowy environments? Oikos 105, 255-267.

Fooden, J., 2006. Comparative review of Fascicularis-group species of macaques (Primates: Macaca). Fieldiana Zool. 107, 1-43.

Freeman, P.W., 1981. A multivariate study of the family Molossidae (Mammalia, Chiroptera): morphology, ecology, evolution. 1981. Field. Zool 7, 1-105.

Friesen, C., Uhrig, E.J., Squire, M.J., Mason, R., Brennan, P.L.R., 2014. Sexual conflict over mating in red-sided gartersnakes (Thamnophis sirtalis) as evidenced by experimental manipulation of genitalia. Proc. Royal Soc. B 28120132694.

Glucksmann, A., Ooka-Souda, S., Miura-Yasug, E., Mizuno, T., 1976. The effect of neonatal treatment of male mice with antiandrogens and of females with androgens on the development of the os penis and os clitoridis. J. Anat. 121, 363-370.

Gregorin, R., 2009. Phylogeny of Eumops Miller, 1906 (Chiroptera: Molossidae) using morphological data. Acta Chiropterol. 11, 247-258.

Gregorin, R., Cirranello, A., 2016. Phylogeny of Molossidae Gervais (Mammalia: Chiroptera) inferred by morphological data. Cladistics 32, 2-35.

Harcourt, A.H., Harvey, P.H., Larson, S.G., Short, R.V., 1981. Testis weight, body weight and breeding system in primates. Nature 293, 55-57.

Harrison, L., Matthews, M.A., 1937. The form of the penis in the British rhinolophid bats, compared with that in some vespertilionid bats; and (2) the female sexual cycle in the British horse-shoe bats, Rhinolophusferrum-equinuminsulanus Barrett-Hamilton and $R$. hypposiderosminutus Montagu. J. Zool. 23, 213-223.

Hatzichristou, D.G., Tzortzis, V., Hatzimouratidis, K., Apostolidis, A., Moysidis, K. Panteliou, S., 2003. Protective role of the glans penis during coitus. Int. J. Impot. Res. $15,337-342$.

Herdina, A.N., Herzig-Straschil, B., Hilgers, H., Metscher, B.D., Plenk Jr., H., 2010. Histomorphology of the penis bone (baculum) in the gray long-eared bat Plecotus austriacus (Chiroptera, Vespertilionidae). Anat. Rec. 293, 1248-1258.

Herdina, A.N., Hulva, P., Horáček, I., Benda, P., Mayer, C., Hilgers, H., Metscher, B.D., 2014. MicroCT imaging reveals morphometric baculum differences for discriminating the cryptic species Pipistrellus pipistrellus and P. pygmaeus. Acta Chiropterol. 16, $157-168$.

Herdina, A.N., Kelly, D.A., Jahelková, H., Lina, P.H., Horáček, I., Metscher, B.D., 2015a. Testing hypotheses of bat baculum function with 3D models derived from microCT. J. Anat. 226, 229-235.

Herdina, A.N., Plenk, H., Benda, P., Lina, P.H., Herzig-Straschil, B., Hilgers, H., Metscher, B.D., 2015b. Correlative 3D-imaging of Pipistrellus penis micromorphology: validating quantitative microCT images with undecalcified serial ground section histomorphology. J. Morphol. 276, 695-706.

Herdina, A.N., Nugraha, T.P., Semiadi, G., Haase, A., Lina, P.H., Godlevska, L., Vlaschenko, A., Metscher, B.D., 2016. Bat development: interspecies differences in baculum ossification patterns. The FASEB Journal 30 (Supplement) 1039. 3-1039.3.

Hill, J.E., Harrison, D.L., 1987. The baculum in the Vespertilioninae (Chiroptera Vespertilionidae) with a systematic review, a synopsis of Pipistrellus and Eptesicus, and the descriptions of a new genus and subgenus. Bull. Br. Mus. Nat. Hist. Zool. 52, 225-305.

Holmes, G.M., Chappel, W.D., Leipheimer, R.E., Sachs, B.D., 1991. Electromyographic analysis of male rat perineal muscles during copulation and reflexive erections. Physiol. Behav. 49, 1235-1246.

Hoofer, S.R., Van Den Bussche, R.A., Horácek, I., 2006. Generic status of the American pipistrelles (Vespertilionidae) with description of a new genus. J. Mammal. 87, 981-992.

Hosken, D.J., Stockley, P., 2004. Sexual selection and genital evolution. Trends Ecol. Evol. 19, 87-93.

Hotzy, C., Polak, M., Rönn, J.L., Arnqvist, G., 2012. Phenotypic engineering unveils the function of genital morphology. Curr. Biol. 22, 2258-2261.

Howell, A.H., 1938. Revision of the North American ground squirrels, with a classification of the North American Sciuridae. N. Amer. Fauna 56, 1-256.

Hull, E.M., Dominguez, J.M., 2007. Sexual behavior in male rodents. Horm. Behav. 52, 45-55.

Hull, E.M., Rodríguez-Manzo, G., 2009. Male sexual Behavior. In: In: Pfaff, D.W., Arnold, A.P., Fahrbach, S.E., Etgen, A.M., Rubin, R.T. (Eds.), Hormones, Brain and Behavior, vol 2. Academic Press, San Diego, pp. 5-65.

Jacobs, D.S., Babiker, H., Bastian, A., Kearney, T., van Eeden, R., Bishop, J.M., 2013. Phenotypic convergence in genetically distinct lineages of a Rhinolophus species complex (Mammalia, Chiroptera). PloS One 8, e82614.

Jones, J.C., Fruciano, C., Keller, A., Scharti, M., Meyer, A., 2016. Evolution of the elaborate male intromittent organ of Xiphophorus fishes. Ecol. Evol. 6, 7207-7722.

Kamikawa-Miyado, M., Ogi, H., Ogino, Y., Katoh, H., Suzuki, K., Uemura, M., Kitoh, J., Oda, S., Yamada, G., 2005. The morphological and histological characters of the male external genitalia of the house musk shrew. Zool. Sci. 22, 463-468.

Keeley, A.T.H., Keeley, B.W., 2004. The mating system of Tadarida brasiliensis (Chiroptera: Molossidae) in a large highway bridge colony. J. Mammal. 85, 113-119.

Kelly, D.A., 2000. Anatomy of the baculum-corpous cavernosum interface in the Norway rat (Rattus novergicus), and implications for force transfer during copulation. J. Morphol. 244, 69-77.

Klaczko, J., Ingram, T., Losos, J., 2015. Genitals evolve faster than other traits in Anolis lizards. J. Zool. 295, 44-48.

Krutzsch, P.H., 1975. Reproduction of the canyon bat, Pipistrellus hesperus, in Southwestern United States. Am. J Anat. I43, 163-200.

Krutzsch, P.H., Crichton, E.G., 1987. Reproductive biology of male little mastiff bat, Mormopterus planiceps (Chiroptera: Molossidae), in Southeast Australia. Am. J. Anat. 
178, 352-368.

Krutzsch, P.H., Watson, R.H., Lox, C.D., 1976. Reproductive biology of the male leafnosed bat, Macrotus waterhousii in Southwestern United States. Anat. Rec. 184 611-635.

Langerhans, R.B., Layman, C.A., DeWitt, T.J., 2005. Male genital size reflects a tradeoff between attracting mates and avoiding predators in two live-bearing fish species. Proc. Natl. Acad. Sci. USA 102, 7618-7623.

Leite-Silva, C., Santos, N., Fagundes, V., Yonenaga-Yassuda, Y., Souza, M.J., 2003. Karyotypic characterization of the bat species Molossus ater, M. molossus and Molossops planirostris (Chiroptera, Molossidae) using FISH and banding techniques. Hereditas 138, 94-100.

Lessa, E.P., Cook, J.A., 1989. Interspecific variation in penial characters in the genus Ctenomys (Rodentia: Octodontidae). J. Mammal. 70, 856-860.

Lidicker, W., Yang, A., 1986. Morphology of the penis in the Taiga vole (Microtus xanthognathus). J. Mammal. 67, 497-502.

Long, C.A., 1969. Gross morphology of the penis in seven species of the Mustelidae. Mammalia 33, 145-160.

Long, C.A., Frank, T., 1968. Morphometric variation and function in the baculum, with comments on correlation of parts. J. Mammal. 49, 32-43.

Marler, P., 1957. Specific distinctiveness in the communication signals of birds. Behaviour 11, 13-39.

Matthews, L.H., 1937. The form of the penis in the British rhinolophid bats, compared with that of the vespertilionid bats. Trans. Zool. Soc. Lond. 23, 213-223.

Matthews, L.H., 1941. Notes on the genitalia and reproduction of some African bats. J. Zool, Proc. Zool. Soc. London Ser. B 3, 289-346.

Medina, C.E., Gregorin, R., Zeballos, H., Zamora, H.T., Moras, L.M., 2014. A new species of Eumops (Chiroptera: Molossidae) from southwestern Peru. Zootaxa 3878, 19-36.

Moller, A.P., 1988. Ejaculate quality, testes size and sperm competition in primates. J. Hum. Evol. 17, 479-488.

Moras, L.M., Tavares, V.C., Pepato, A.R., Santos, F.R., Gregorin, R., 2016. Reassessment of the evolutionary relationships within the dog-faced bats, genus Cynomops (Chiroptera: Molossidae). Zool. Scripta 45, 465-480.

Morielle-Versute, E., Varella-Gracia, E.M., Taddei, V.A., 1996. Karyotypic patterns of seven species of molossid bats (Molossidae, Chiroptera). Cytogenet. Cell Genet. 72 26-33.

Murakami, R., Mizuno, T., 1984. Histogenesis of the os penis and os clitoridis in rats. Dev. Growth Differ. 26, 419-426.

Orr, T.J., Brennan, P.L.R., 2016. All features great and small - the potential roles of the baculum and penile spines in mammals. Integr. Comp. Biol. 56, 635-643.

Patterson, B.D., Thaeler Jr., C., 1982. The mammalian baculum: hypotheses on the nature of bacular variability. J. Mammal. 63, 1-15.

Peters, S.L., Lim, B.K., Engstron, M.D., 2002. Systematics of dog-faced bats (Cynomops) based on molecular and morphometric data. J. Mammal. 83, 1097-1110.

Perkin, A., 2007. Comparative penile morphology of East African galagos of the genus Galagoides (family Galagidae): implications for taxonomy. Am. J. Primatol. 69, 16-26.

Purohit, R.C., Beckett, S.D., 1976. Penile pressures and muscle activityassociated with erection and ejaculation in the dog. Am. J. Physiol-Legacy Content 231, 1343-1348.

Ramm, S.A., 2007. Sexual selection and genital evolution in mammals: a phylogenetic analysis of baculum length. Am. Nat. 169, 360-369.

Rauther, M., 1903. Bemerkungen über den Genitalapparat und die Analdrüsen der Chiropteren. Anat. Anz. 23, 508-524.

Reardon, T.B., McKenziec, N.L., Cooper, S.J.B., Appleton, B., Carthew, S., Adams, M., 2014. A molecular and morphological investigation of species boundaries and phylogenetic relationships in Australian free-tailed bats Mormopterus (Chiroptera: Molossidae). Aust. J. Zool. 62, 109-136.

Rodriguez Jr., E., Weiss, D.A., Yang, J.H., Menshenina, J., Ferretti, M., Cunha, T.J., Barcellos, D., Chan, L.Y., Risbridger, G., Cunha, G.R., Baskin, L.S., 2011. New insights on the morphology of adult mouse penis. Biol. Reprod. 85, 1216-1221.

Rönn, J., Katvala, M., Arnqvist, G., 2007. Coevolution between harmful male genitalia and female resistance in seed beetles. Proc. Natl. Acad. Sci. USA 104, 10921-10925.

Rossi, L.F., Luaces, J.P., Aldana Marcos, H.J., Cetica, P.D., Pérez Jimeno, G., Merani, M.S., 2012. Anatomy and histology of the male reproductive tract and spermatogenesis fine structure in the lesser anteater (Tamandua tetradactyla; Myrmecophagidae, Xenarthra): morphological evidences of reproductive functions. Anat. Histol. Embryol. 42, 247-256.

Rowe, L., Arnqvist, G., 2011. Sexual selection and the evolution of genital shape and complexity in water striders. Evolution 66, 40-54.

Ryan, J.M., 1991a. Comparative morphology of the glans penis in Molossus, Promops and Eumops (Chiroptera: Molossidae) Contributions to mammalogy in honor of Karl F.
Koopman. Bull. Am. Mus. Nat. Hist. 206, 122-137.

Ryan, J.M., 1991b. Morphology of the glans penis in four genera of molossid bats (Chiroptera: Molossidae). J. Mammal. 72, 658-668.

Sachs, B.D., Glater, G.B., ÓHanlon, J.K., 1984. Morphology of the erect glans penis in rats under various gonadal hormone conditions. Anat. Rec. 210, 45-52.

Schultz, N.G., Ingels, J., Hillhouse, A., Wardwell, K., Chang, P.L., Cheverud, J.M., Lutz, C. Williams, R.W., Dean, M.D., 2016a. The genetic basis of baculum size and shape variation in mice. Genes Genom. Genet. 6, 1141.

Schultz, N.G., Lough-Stevens, M., Abreu, E., Orr, T., Dean, M., 2016b. The baculum was gained and lost multiple times during mammalian evolution. Integr. Comp. Biol. 56, 644-656.

Silva, M.A., Villasen̂or, M.R.V., Márquez, S.R., Gonzáles, M.H., Jaime, H.B., García, X.G., Montiel, J.L.C., 2013. Testosterone levels and development of the penile spines and testicular tissue during the post natal growth and wistar rats. Adv. Sex Med. 3, 1-9.

Simmons, N.B., 2005. Order Chiroptera. In: Wilson, D.E., Reeder, D.M. (Eds.), Mammal Species of the World: A Taxonomic and Geographic Reference, 3rd edition. Johns Hopkins University Press, Baltimore, pp. 312-529.

Simmons, L.W., 2014. Sexual selection and genital evolution. Austral. Entomol. 53, 1-17.

Simmons, L.W., Firman, R.C., 2014. Experimental evidence for the evolution of the Mammalian baculum by sexual selection. Evolution 68, 276-283.

Simmons, L.W., Garcia-Gonzalez, F., 2011. Experimental coevolution of male and female genital morphology. Nat. Commun. 2, 374.

Simmons, L.W., House, C.M., Hunt, J., García-Gonzalez, F., 2009. Evolutionary response to sexual selection in male genital morphology. Curr. Biol. 19, 1442-1446.

Smirnov, D.G., Tsytsulina, K., 2003. The ontogeny of the baculum in Nyctalus noctula and Vespertilio murinus (Chiroptera: Vespertilionidae). Acta Chiropterol. 5, 117-123.

Smith, J.D., Madkour, G., 1980. Penial morphology and the question of Chiroptera phylogeny. In: Wilson, D.E., Gardner, A.L. (Eds.), Proceedings of the Fifth International Bat Research Conference. Texas Tech Press, Lubbock. pp. 347-365.

Spitzenberger, F., Strelkov, P.P., Winkler, H., Haring, E., 2006. A preliminary revision of the genus Plecotus (Chiroptera, Vespertilionidae) based on genetic and morphological results. Zool. Scr. 35, 187-230.

Stockley, P., 2002. Sperm competition risk and male genital anatomy: comparative evidence for reduced duration of female sexual receptivity in primates with penile spines. Evol. Ecol. 16, 123-137.

Stockley, P., 2012. The baculum. Curr. Biol. 22, 2285-2382.

Stockley, P., Ramm, S.A., Sherborne, A.L., Thom, M.D.F., Paterson, S., Hurst, J.L., 2013. Baculum morphology predicts reproductive success of male house mice under sexual selection. BMC Biol. 11, 66.

Taylor, W.R., 1967. An enzyme method of clearing and staining small vertebrates. Proc. U.S. Natl. Mus. 122, 1-17.

Thomas, M.N., Harrison, D.L., Bates, P.J.J., 1994. A study of the baculum in the genus Nycteris (Mammalia Chiroptera, Nycteridae) with consideration of its taxonomic importance, Bonn. Zool. Beitr. 45, 17-31.

Timm, R.M., Genoways, H.H., 2004. The Florida bonneted bat, Eumops floridanus (Chiroptera: Molossidae): distribution, morphometrics, systematics, and ecology. J. Mammal. 85, 852-865.

Verrell, P.A., 1992. Primate penile morphologies and social systems: further evidence for an association. Folia Primatol. 59, 114-120.

Waage, J.K., 1979. Dual function of the damselfly penis: sperm removal and transfer. Science 203, 916-918.

Weimann, B., Edwards, M.A., Jass, C.N., 2014. Identification of the baculum in American pika (Ochotona princeps: Lagomorpha) from southwestern Alberta, Canada. J. Mammal. 95, 284-289.

Williams, S.L., Hafner, J.C., Dolan, P.G., 1980. Glans penis and bacula of five species of Apodemus (Rodentia: Muridae) from Croatia, Yugoslavia. Mammalia 44, 245-258.

Wimsatt, W.A., Kallen, F.C., 1952. Anatomy and histophysiology of the penis of a vespertilionid bat, Myotis lucifugus lucifugus, with particular reference to its vascular organization. J. Morphol. 90, 415-465.

Woolley, P.A., Krajewski, C., Westerman, M., 2015. Phylogenetic relationships within Dasyurus (Dasyuromorphia: Dasyuridae): quoll systematics based on molecular evidence and male characteristics. J. Mammal. 96, 37-46.

Wrobel, K.H., Bergmann, M., 2006. Male Reproductive System. In: Eurell, J.A., Frappier, B.L. (Eds.), Dellmann's Textbook of Veterinary Histology. Blackwell Publishing, Iowa, pp. 233-255.

Yiee, J.H., Baskin, L.S., 2010. Penile embryology and anatomy. The Sci. World J. 10, 1174-1179.

Yonezawa, T., Higashi, M., Yoshioka, K., Mutoh, K.I., 2011. Distribution of aromatase and sex steroid receptors in the baculum during the rat life cycle: effects of estrogen during the early development of the baculum. Biol. Reprod. 85, 105-112. 